Portland State University

PDXScholar

\title{
Socio-Spatial Differentiation in the Sustainable City: A Mixed-Methods Assessment of Residential Gardens in Metropolitan Portland, Oregon, USA
}

\author{
Nathan McClintock \\ Portland State University, n.mcclintock@pdx.edu \\ Dillon Mahmoudi \\ Portland State University \\ Michael Simpson \\ Portland State University \\ Jacinto Pereira Santos \\ Universidade Federal de Tocantins
}

Follow this and additional works at: https://pdxscholar.library.pdx.edu/usp_fac

Part of the Urban Studies and Planning Commons

Let us know how access to this document benefits you.

\section{Citation Details}

McClintock, N., Mahmoudi, D., Simpson, M., \& Santos, J. P. (2016). Socio-spatial differentiation in the Sustainable City: A mixed-methods assessment of residential gardens in metropolitan Portland, Oregon, USA. Landscape and Urban Planning, 148, 1-16.

This Post-Print is brought to you for free and open access. It has been accepted for inclusion in Urban Studies and Planning Faculty Publications and Presentations by an authorized administrator of PDXScholar. Please contact us if we can make this document more accessible: pdxscholar@pdx.edu. 
Forthcoming in Landscape and Urban Planning

Accepted December 12, 2015

\title{
Socio-spatial differentiation in the Sustainable City: A mixed-methods assessment of residential gardens in metropolitan Portland, Oregon, USA
}

\author{
Nathan McClintock* \\ Dillon Mahmoudi \\ Michael Simpson ${ }^{1}$ \\ Jacinto Pereira Santos ${ }^{2}$
}

Toulan School of Urban Studies \& Planning, Portland State University, P.O. Box 751, Portland, OR 97207, USA

\begin{abstract}
As cities take center stage in developing and brokering strategies for sustainability, examining the uneven distribution of green infrastructure is crucial. Urban agriculture (UA) has gained a prominent role in urban greening and food system diversification strategies alike. Despite that it is the preeminent form of food production in North American cities, residential gardening has received little scholarly attention. Moreover, research on the intra-urban variability of home gardens is sparse. In this paper, we use a mixed-methods approach to assess the scale and scope of residential gardens in Portland, Oregon, a metropolitan region renowned for its innovations in sustainability. Using a combination of mapping, spatial regression, and a mail survey, we compare residential UA and the characteristics and motivations of gardeners in two socioeconomically differentiated areas of Portland and one of its major suburbs. Results demonstrate that engagement in UA is differentiated both along spatial and socioeconomic lines, with more educated respondents engaging for environmental reasons and more low-income respondents relying on their gardens for food security. We contextualize our findings within broader urban processes, e.g. reinvestment in the urban core and displacement of poverty to the periphery. For policymakers, our results suggest the need for sustainability messaging that is sensitive to a variety of motivations and that resonates with a diverse population. For a city to reach a broader population, it may need to reframe its sustainability goals in new ways, while attending to the structural constraints to food access that cannot be resolved through local food production alone.
\end{abstract}

Keywords: equity; food systems planning; gardens; mixed-methods; sustainability; urban agriculture

\footnotetext{
${ }^{*}$ Corresponding author.

Email: n.mcclintock@pdx.edu; Tel. +1 503725 4064; Fax +1 5037258770

${ }^{1}$ Current address: Department of Geography, University of British Columbia, 1984 West Mall, Vancouver, BC, Canada V6T 1 Z2

${ }^{2}$ Permanent address: Colegiado de Agronomia, Universidade Federal do Tocantins, Cx. Postal 66, CEP 77402-970, Gurupi, TO, Brazil
} 


\section{Introduction}

How to feed an increasingly urbanized world in an ecologically sustainable - and socially equitable - manner is a critical question that policymakers have grappled with over the past few decades. As a complementary, decentralized node of food production and distribution, urban agriculture (UA) has gained a prominent role in municipal efforts to diversify urban food systems while greening urban landscapes in North America (Hodgson, Caton Campbell, \& Bailkey, 2011; Jansson, 2013). Defined here as the production of food crops and livestock within urbanized areas, UA takes a variety of forms, including: allotment or community gardens; commercial market gardens and urban farms; organizational and institutional gardens run by non-governmental organizations, churches, schools, and community groups; and residential or home gardens. While few claim that UA can meet all of the food needs of a city (Grewal \& Grewal, 2012; MacRae et al., 2010; McClintock, Cooper, \& Khandeshi, 2013), many have argued that UA can nevertheless enhance the resilience of urban food systems vis a vis environmental or economic variability and shocks (Barthel \& Isendahl, 2013; Krasny \& Tidball, 2009; Okvat \& Zautra, 2011).

Urban agriculture serves multiple functions. Studies highlight how gardens provide a suite of ecosystems services, including improving stormwater infiltration, reducing urban heat island effect, sequestering soil carbon, enhancing biodiversity, and reducing greenhouse gases by reducing the distance that food travels between production and consumption (Guitart, Byrne, \& Pickering, 2013; Lin, Philpott, \& Jha, 2015; McPhearson, Hamstead, \& Kremer, 2014; Moglia, 2014; Pearson, Pearson, \& Pearson, 2010). The social benefits of UA are also varied, and include: improving nutritional and mental health (Alaimo, Packnett, Miles, \& Kruger, 2008; Armstrong, 2000); fostering community interactions and cohesion (Ghose \& Pettygrove, 2014; Saldivar-Tanaka \& Krasny, 2004); serving as a rallying ground for food justice and food sovereignty activism in low-income communities (Bradley \& Galt, 2014; Ramírez, 2015; Sbicca, 2012; White, 2011); and mitigating urban food insecurity (Bradley \& Galt, 2014; Gray, Guzman, Glowa, \& Drevno, 2014). Finally, scholars and practitioners have also emphasized UA's economic benefits, from offsetting household food costs (Gray et al., 2014; Kortright \& Wakefield, 2011) to creating jobs (Smit et al. 1996; van Veenhuizen 2006) and increasing land values (Voicu \& Been, 2008). With these benefits in mind, urban sustainability planners have embraced UA and dozens of cities have made changes to policies and land use controls in hopes of encouraging urban food production (Hodgson et al., 2011; Thibert, 2012).

While there has been a significant expansion of community gardens and commercial agriculture in cities over the past decade (Drake \& Lawson, 2014; Rogus \& Dimitri, 2015), most urban food production continues to take place at the residential scale. But as Taylor and Lovell (2014) point out, scholarship on residential food production in the Global North is sparse, and the scale of home gardening rarely quantified. Estimates vary considerably within and across countries of the Global North. One study estimated that about 25\% urban and suburban households - about 30 million overall - in the US produce some of their own food (National Gardening Association, 2014), while a study in Ohio reported 39 to $41 \%$ of urban and suburban residents had a household food garden (Schupp \& Sharp, 2012). In another study, 48\% of respondents reported gardening at home and $8 \%$ in community gardens (Comstock et al., 2010). A Canadian study of domestic food production came to similar conclusions: $40 \%$ of Toronto residents and 44\% of Vancouver residents reported that someone in their household grew food (City Farmer, 2002), while a 2013 survey conducted by the City of Montreal reported 42\% of 
people produced food at home (Ville de Montréal, 2013). Productivity varies widely. CoDyre et al. (2015), for example, reported that home gardeners in Ontario were able to grow between 0.08 and $5.18 \mathrm{~kg} \mathrm{per} \mathrm{m}^{2}$. Similarly, in a review of data from seven North American cities, McClintock (2014) reported garden yields ranging from 0.56 to 60.09 metric tons per hectare. Even less clear is intra-urban variability of urban food production, that is, the ways that the presence and function of UA differ within a city or neighborhood. A number of studies have explored such socio-spatial variation in relation to trees (Martin, Warren, \& Kinzig, 2004), lawns (Giner, Polsky, Pontius Jr., \& Runfola, 2013), biodiversity (Kinzig, Warren, Martin, Hope, \& Katti, 2005), and community and organizational gardens (Guitart et al., 2013; Kremer \& DeLiberty, 2011; Pourias, Aubry, \& Duchemin, 2015), but scholars have only recently begun to examine such variation in relation to residential UA (Hunter \& Brown, 2012; V. M. Smith, Greene, \& Silbernagel, 2013; Taylor \& Lovell, 2012, 2015).

Addressing the socio-spatial differentiation of UA is vital, given that the benefits of urban sustainability are rarely evenly distributed: for example, urban green space and tree canopy often correlate with socioeconomic stratification (Pham, Apparicio, Séguin, Landry, \& Gagnon, 2012); low-income populations of color tend to have less access to parks and open space (Wolch, Byrne, $\&$ Newell, 2014); and more affluent white populations are more likely to live in neighborhoods with mature trees or extensive canopy (Heynen, Perkins, \& Roy, 2006). While some have attributed these disparities to the historical legacies of previous eras of development (Boone, Cadenasso, Grove, Schwarz, \& Buckley, 2010), critical geographers have shed light on how such stratification is ongoing. Despite dominant sustainability narratives suggesting that green infrastructure benefits everyone, some sustainability efforts have instead alienated historically marginalized groups who feel that the new infrastructure is marketed toward eco-conscious affluent newcomers, rather than meeting the immediate needs of longtime residents (Checker, 2011; Goodling, Green, \& McClintock, 2015; Lubitow \& Miller, 2013; Pearsall, 2012).

Arising in response to these disparities in distribution and access to green infrastructure, and to the relative absence of explicit equity concerns in sustainability policy (Pearsall \& Pierce, 2010), a "just sustainability" paradigm integrates the environmental focus of the dominant sustainability framework with the justice concerns of marginalized populations (Agyeman, 2013). Asking "Sustainable for whom?" researchers and planners embracing a just sustainability framework are concerned not only with equalizing access to the fruits of sustainability innovations, but also with how these same innovations may actually exacerbate existing disparities.

Food access fits squarely within this framework. Researchers have exposed disparities within sustainable food systems efforts in North America, revealing that alternative food sources such as farmers markets and UA are often dominated by - and disproportionately benefit - a predominantly white, educated, and affluent population, often by invoking environmental-, ecological-, and sustainability-oriented discourse (Alkon \& Agyeman, 2011). Even in so-called "food deserts" (low-income areas with limited access to grocery stores or supermarkets), gardening efforts intended to improve access to healthy food tend to be dominated by young, educated, and usually white outsiders, alienating people of color by reproducing dominant hierarchies of power (Lyson, 2014; Ramírez, 2015; Slocum, 2007). Such disparities are further exacerbated as UA organizations led by this same demographic disproportionately receive grant funding and other support from public and private sources (Cohen \& Reynolds, 2014; Reynolds, 2015).

With this concern for just sustainability in mind, we turn to our study of residential 
gardens in metropolitan Portland, a paradigmatic "Sustainable City" heralded for its innovative sustainability efforts. The goal of our study is twofold: first, to determine the extent to which residential UA - and its potential contribution to urban food system resilience - occurs in a spatially and socioeconomically uneven manner; and second, to determine whether the motivations of gardeners differ along these same socio-spatial lines and, if so, how. We begin by describing our study site of metropolitan Portland, Oregon, then present our mixed-methods approach to assessing both the scale and scope of residential food production, comparing production in two socioeconomically differentiated areas of Portland - Inner and East Portland and in one of the city's major suburbs, Vancouver, Washington. Through mapping of gardens, spatial regression to determine explanatory factors, and a mail survey to determine the characteristics and motivations of gardeners, we demonstrate how engagement in UA is differentiated along spatial and socioeconomic lines. We conclude with a discussion of these results, limitations and strengths of the study, and implications for urban food systems planning.

\section{Study Area and Methods}

\subsection{Study area}

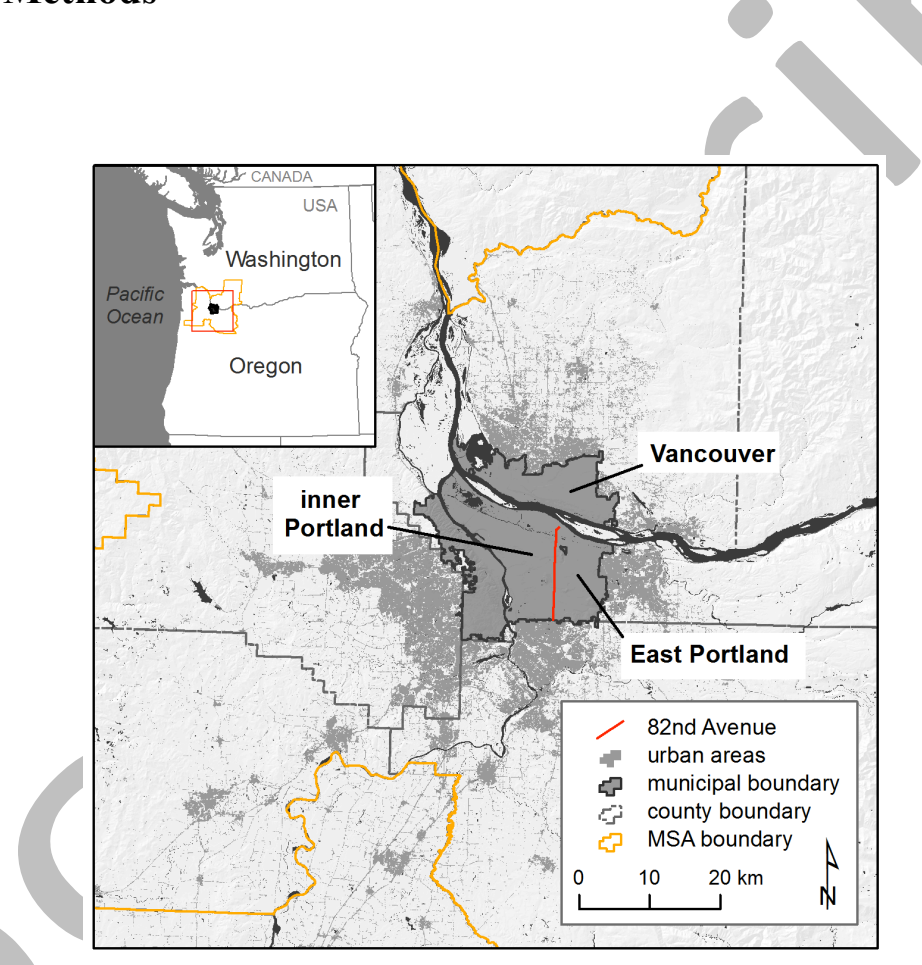

Figure 1. Study area. Portland, Oregon, USA, straddling the Willamette River and its suburb of Vancouver, Washington, which lies to the north across the Columbia River. Portland's $82^{\text {nd }}$ Avenue serves as a rough boundary between the city's older inner-core neighborhoods and the post-war neighborhoods of East Portland, many of which are now lower income and more racially/ethnically diverse. The two cities comprise about one-third of the total population of the Portland-Vancouver-Hillsboro, OR-WA Metropolitan Statistical Area (MSA).

Portland, Oregon is a city of roughly 610,000 people (2013 est.) located at the confluence of the Columbia and Willamette Rivers and is the second largest city in the US Pacific Northwest (see Figure 1). Home to a population of approximately 2.2 million, the greater Portland Metropolitan Statistical Area spans five counties in Oregon, and two in Washington. Portland, like most American cities, is spatially stratified along socioeconomic lines. As the data in Table 1 reveal, East Portland (which comprises the easternmost quarter of the city's area, roughly 
delineated by $82^{\text {nd }}$ Avenue) is home to a disproportionate number of low-income residents and people of color. Vancouver, Washington lies across the Columbia River to the Portland's north and is one of Portland's largest suburbs (see Table 1).

Table 1. Population and socioeconomic characteristics of metropolitan Portland

\begin{tabular}{|c|c|c|c|c|c|}
\hline $\begin{array}{l}\text { Demographic } \\
\text { and socio- } \\
\text { economic } \\
\text { indicators }\end{array}$ & $\begin{array}{l}\text { Metropolitan } \\
\text { Statistical } \\
\text { Area }\end{array}$ & $\begin{array}{l}\text { Portland } \\
\text { All }\end{array}$ & Inner & East & $\begin{array}{l}\text { Vancouver } \\
\text { All }\end{array}$ \\
\hline Population & $2,232,607$ & 593,311 & 427,237 & 166,074 & 162,699 \\
\hline $\begin{array}{l}\text { Pop. Density } \\
\text { (persons/ km²) } \\
\text { Median }\end{array}$ & 129 & 1,584 & 1,554 & 1,667 & \\
\hline $\begin{array}{l}\text { household } \\
\text { income }\end{array}$ & $\$ 57,896$ & $\$ 51,238$ & $\$ 60,138$ & & 271 \\
\hline $\begin{array}{l}\% \text { home } \\
\text { ownership } \\
\% \text { non-white, }\end{array}$ & $62.0 \%$ & $54.3 \%$ & $54.0 \%$ & & $50.2 \%$ \\
\hline $\begin{array}{l}\% \text { non-white, } \\
\text { non- } \\
\text { Hispanic/Latino } \\
\text { population }\end{array}$ & $10.8 \%$ & $27.5 \%$ & $23.1 \%$ & $8.8 \%$ & $9.9 \%$ \\
\hline $\begin{array}{l}\% \text { college- } \\
\text { educated }\end{array}$ & $34.3 \%$ & $43.1 \%$ & $51.9 \%$ & $18.6 \%$ & $23.7 \%$ \\
\hline $\begin{array}{l}\text { Economic } \\
\text { integration }\end{array}$ & 0.41 & 0.29 & 0.33 & 0.41 & 0.31 \\
\hline
\end{tabular}

Source: American Community Survey 5-Year Sample 2008-2012 and authors' calculations. Portland, Inner Portland, and East Portland approximate to block groups comprising the Portland city boundary and include household weighted averages for median household incomes.

Portland has, in many ways, become a model of sustainable planning, renowned for its robust green infrastructure, including bike lanes, LEED-certified buildings, bioswales, and light rail system (Cotugno \& Seltzer, 2011). Municipal policies to improve neighborhood walkability and mitigate greenhouse gas emissions have earned the city a regular place at the top of numerous rankings of sustainability and livability. A robust local food system further advances Portland's reputation as a vibrant sustainability capital. Various farm-to-institution arrangements, farm-to-table restaurants, "pods" of mobile food carts, and an extensive network of urban gardens all contribute to the city's commitment to "develop policy and provide programmatic resources to significantly increase the percentage of home-grown and locally sourced food" (City of Portland \& Multnomah County, 2009, p. 53). The 2012 Urban Food Zoning Update, for example, lifted several zoning restrictions related to community gardens and the sale of produce grown in residential gardens (City of Portland, 2012). Home gardens also figure into municipal resilience strategies. The "Planning for Resilience and Emergency Preparedness" website, a resource for Bureau of Emergency Management's Neighborhood Emergency Teams, provides information on "long-term resilience" strategies such as growing and preserving food to help buffer against natural disasters, economic instability, extreme weather events, or energy shocks (PREP Oregon, 2015). 
Portland's UA landscape is diverse: 50 community gardens managed by the City of Portland, more than 80 school gardens, nearly 30 market gardens, and dozens of organizational gardens (McClintock, Young, Taren, Simpson, \& Santos, 2013). Residential gardens are ubiquitous in many Portland neighborhoods. Many residents cultivate in raised beds located in their yards (see Figure 2a) or in the right-of-way between the sidewalk and street (see Figure 2b). As the city allows up to three chickens, ducks, goats, and rabbits without a permit, many people also raise small livestock in their yards.

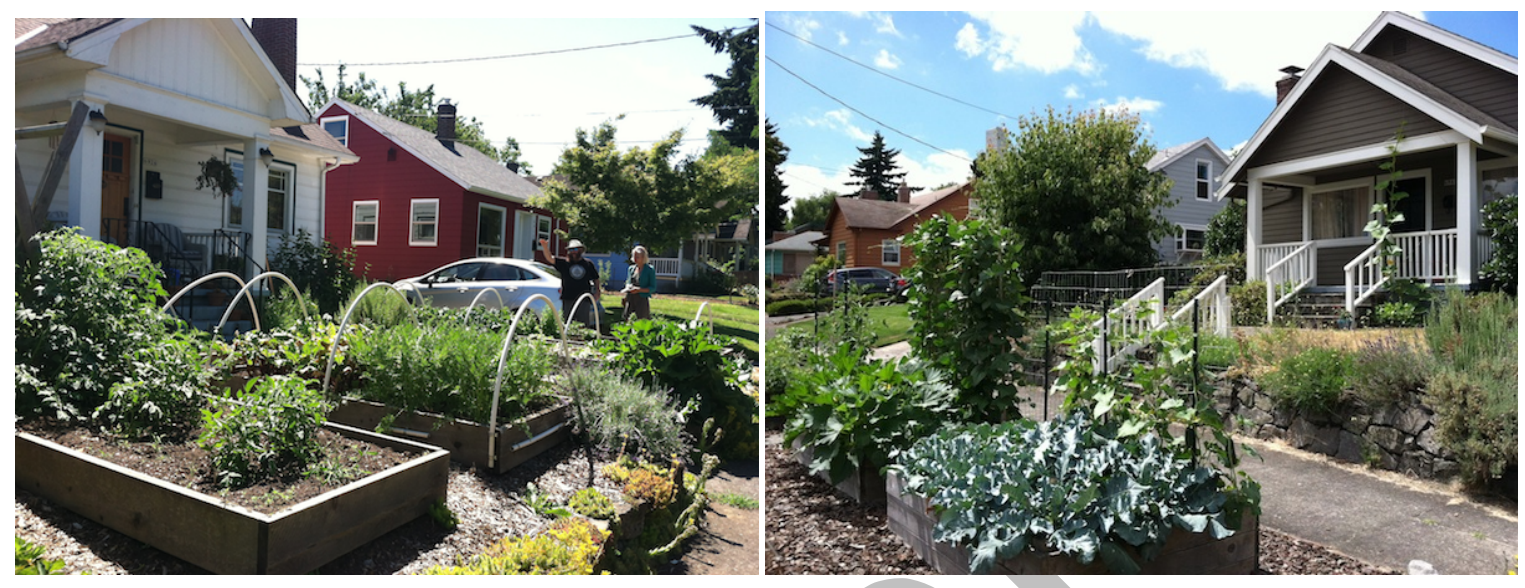

Figure 2. Raised garden beds in a front yard (a) and on the right-of-way between the sidewalk and street (b), both located in Inner Portland. Photos by N. McClintock.

Despite - or perhaps due to - the ubiquity of residential gardens in Portland, there has been no comprehensive attempt to map them that we are aware of. Given the growing socioeconomic disparity between East Portland and Inner Portland (Goodling et al., 2015), we pay special attention to this intra-urban geographic demarcation. We have also included an additional inter-urban comparison between Portland and its suburb of Vancouver. Given starkly different regulatory frameworks governing land use in Oregon and Washington, different demographic, socioeconomic, and political characteristics - it is a whiter, more conservative suburb - Vancouver serves as a potentially interesting analytical foil to left-leaning, urban Portland.

\subsection{Methods}

\subsubsection{Visual identification and classification of gardens}

We obtained Portland tax lot data from Metro (greater Portland's regional government charged with land use planning) and Vancouver tax lot data from the University of Washington's Suzallo Map Collection. Following Taylor and Lovell (2012), we used Google Earth Pro to scan August 2012 aerial imagery of Portland and Vancouver. Systematically following a $250 \mathrm{~m} \times 250 \mathrm{~m}$ grid with non-residential properties masked, we visually classified any area over $1 \mathrm{~m}^{2}$ that appeared to be a garden, i.e., clearly delineated beds or planting area, on a residential parcel (tax lot) within the Portland and Vancouver city limits. We traced a polygon around its boundaries (see Figure 3) and recorded the number of beds within the polygon and its location in relation to the street (front yard vs. side or back yard). 


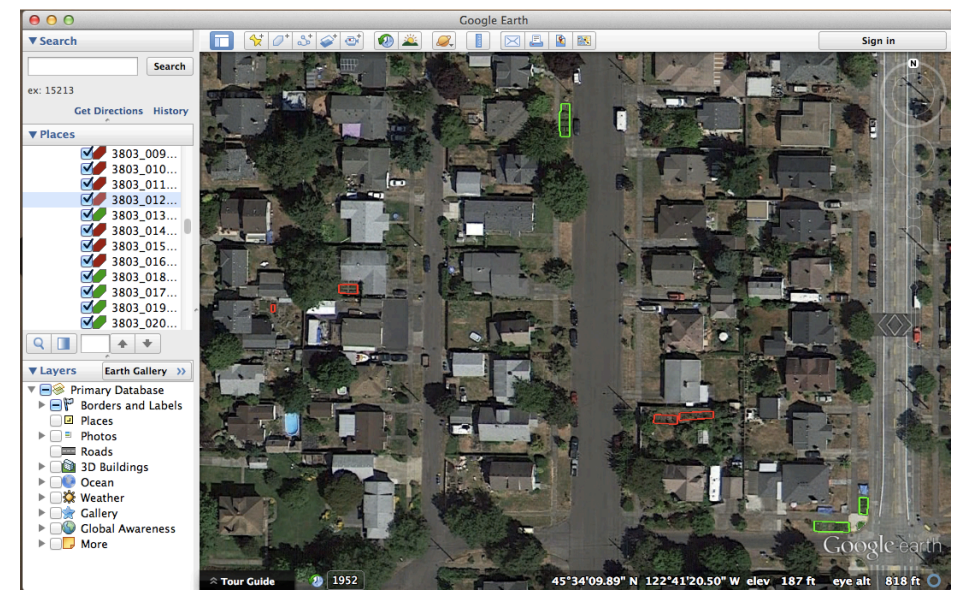

Figure 3. Screenshot of a Portland household with both a front and back garden mapped using Google Earth.

We then used ArcGIS to calculate the area of each polygon, and accounted for nonproductive space in gardens with more than one bed by adjusting the area using a coefficient for a given number of beds. To calculate this, we randomly selected a subset of 20 gardens for each number of beds $(2,3,4,5,6$, or $7+)$ and measured the total area between beds (i.e., the aisles) to calculate a ratio of cultivated area to total area. We multiplied the total area of each garden by this coefficient, which ranged from 0.63 to 0.70 , to calculate what we call the "productive area". In cases where a single tax lot contained multiple gardens, we aggregated the productive area.

We joined the garden layer with residential tax lot layers and US census block group layers. As we wanted to limit our study to household-scale production, we then removed all tax lots not classified as single-family residential (SFR). We aggregated garden data for each census block group, and calculated a location quotient (LQ) for each block group to measure the share of gardens in each relative to the citywide total (Isard, 1967; Leigh, 1970). We used the following formula to calculate the garden LQ for each block group:

$$
L Q_{\text {gardens }}=\frac{\text { gardens } b g}{\text { taxlotsbg }_{\text {ax }}} / \frac{\text { garden }_{\mathrm{c} w}}{\text { taxlots }_{\mathrm{c} w}}
$$

where $b g$ indicates the census block group total and $c w$ the citywide total of gardens and SFR tax lots. Using a LQ (rather than count) reduces bias introduced by the heterogeneity of SFR tax lot size and density across the city. For each block group, a garden LQ value of less than 1 indicates that the proportion of SFR tax lots with a garden is less than the citywide average. A value of greater than 1 indicates that the proportion of dwelling units with a garden is more than the citywide average, while a value of 1 indicates that the proportion of dwelling units with a garden is equal to the citywide average. To calculate the LQ for front or back gardens, we modified Equation 1 as follows:

$$
L Q_{\text {fbgardens }}=\frac{\text { fbgardens } b g}{\text { gardens } b g} / \frac{\text { fbgarden } \boldsymbol{s}_{\mathrm{c} w}}{\text { garden } \boldsymbol{s}_{\mathrm{c} w}}
$$

where fbgardens indicates either front or back gardens and gardens indicates all gardens. 


\subsubsection{Validating accuracy via ground-truthing and canopy cover analysis}

We first used the Streetview function to confirm that every garden visible from the street was actually a garden. To further assess accuracy of visual classification and to determine whether canopy cover might contribute to undercount, we then selected seven block groups with one or more front yard gardens for groundtruthing in August 2013. We purposively selected block groups with at least one front yard garden from different geographic zones of Portland representing varying urban form (e.g., densely built Inner N, NE, and SE, and more sprawling SW and E). In August 2013, we drove along every street in each of the seven block groups, verifying mapped front yard gardens and marking new gardens that we had not identified using Google Earth. We then compared our groundtruthing results with Google Earth imagery from July 2013 and August 2012 to determine whether garden undercount was due to visual classification error or because they had been constructed since our preliminary mapping. Using SPRING remote sensing software to classify 2011 National Agriculture Imagery Program infrared imagery, we then calculated canopy cover for each of the seven block groups (see Table 2) and used a linear regression model to calculate the relationship between canopy cover and undercount.

Table 2. Groundtruthing and canopy cover of seven block groups

\begin{tabular}{lccccc}
\hline $\begin{array}{l}\text { Census } \\
\text { tract }\end{array}$ & $\begin{array}{c}\text { Block } \\
\text { group }\end{array}$ & Location & $\begin{array}{c}\text { Pop. } \\
\text { density } \\
\text { (persons/ } \\
\left.\mathrm{km}^{2}\right)\end{array}$ & $\begin{array}{c}\text { Under- } \\
\text { count }\end{array}$ & $\begin{array}{c}\text { Canopy } \\
(\%)\end{array}$ \\
\hline 15 & 1 & $\begin{array}{c}\text { Inner SE } \\
\text { Inner }\end{array}$ & 3,383 & 1 & 20.4 \\
19 & 1 & $\begin{array}{c}\mathrm{NE} \\
\text { (nner }\end{array}$ & 3,494 & 2 & 29.6 \\
24.01 & 1 & $\mathrm{NE}$ & 3,000 & 10 & 24.4 \\
38.02 & 2 & $\mathrm{~N}$ & 3,300 & 3 & 17.7 \\
38.03 & 1 & $\mathrm{~N}$ & 4,115 & 12 & 23.2 \\
67.01 & 1 & $\mathrm{SW}$ & 1,863 & 9 & 28.7 \\
81 & 1 & $\mathrm{E}$ & 3,443 & 3 & 14.1 \\
\hline
\end{tabular}

Using GeoDA software, we first tested for spatial autocorrelation (the tendency for similar phenomenon to be spatially related) by calculating the Global Moran's I statistic for garden LQs, front gardens LQs, and back and side garden LQs. For Portland, the Moran's I was significant for all three LQs (see Table 3), allowing us to reject the null hypothesis of random spatial distribution (Anselin, 1995). The positive sign of all three statistics further indicated clustering rather than even distribution. For Vancouver, the Moran's I was significant for only all gardens and front gardens, but the sign was negative, suggesting spatial dispersion rather than clustering. Given the statistical evidence of non-random distribution (with the exception of Vancouver's backyard gardens), we computed the Anselin Univariate Local Moran's I to identify block groups with higher than average garden LQs. 
Table 3. Results of Global Moran's I test of spatial autocorrelation of block group garden location quotients (LQ) in Portland $(\mathrm{n}=442)$ and Vancouver $(\mathrm{n}=116)$

\begin{tabular}{lcccc}
\hline \multirow{2}{*}{ Garden type } & \multicolumn{2}{c}{ Portland, OR } & \multicolumn{2}{c}{ Vancouver, WA } \\
& Moran's I & Z-score & Moran's I & Z-score \\
\hline All gardens & 0.842 & $6.68^{* *}$ & 2.91 & $-4.28^{* *}$ \\
Front yard & 0.678 & $5.40^{* *}$ & 2.77 & $-4.14^{* *}$ \\
Back or side yard & 0.729 & $5.79^{* *}$ & -0.28 & $-0.41 \mathrm{~ns}$ \\
\hline
\end{tabular}

** $\mathrm{p}<0.01$. Manhattan distance method, $400 \mathrm{~m}(0.25 \mathrm{mi})$ distance band

Next we compared an ordinary least squares (OLS) regression model to a spatial lag model in order to determine which independent variables explained variation in garden LQs at the block group level. Our original models included a range of socioeconomic variables related to income, education level, race/ethnicity, single-family home ownership, and neighborhood characteristics, as well as a spatial lag variable to account for spatial autocorrelation of gardens. We compared variance inflation factors (VIF) to test for multicollinearity and removed variables with $\mathrm{VIF}>2$, and then used stepwise regression to eliminate the remaining non-significant $(p>0.10)$ variables. Our final model included four independent variables. First, we included the $\log$ of the non-white population to capture racial/ethnic differentiation. Second, we used percent home ownership as a relative measure of income. Third, we developed an index of block group level economic integration (EI) and segregation to determine the relative mixture of household income within block groups. Rather than simply testing whether the distribution of household income was evenly distributed across the arbitrarily divided household income groups, we wanted to determine whether median household income in each block group represented middleincome households, was evenly distributed across low-, middle- and high-income, or was heavily weighted toward low- or high-income households. We calculated the index as follows:

$$
E I=p c t H_{\text {middle }}-\left|p c t H_{\text {low }}-p c t H H_{\text {upper }}\right|
$$

where $p c t H H_{\text {middle }}$ represents the percent of households in the geography earning between $\$ 35,000$ and $\$ 100,000$ per, $p c t H H_{\text {low }}$ represents the percent of households earning below $\$ 35,000$ per year, and $p c t H H_{\text {upper }}$ represents the percent of households earning above $\$ 100,000$ per year. ${ }^{1}$ Finally, we used the Walk Score API to determine Walk Score for each garden and for the center-point of each block group polygon. An index that integrates distance to amenities such as transit, parks, schools, restaurants, shopping, entertainment and shopping (Walk Score, 2014), Walk Score served in our model as a proxy for the "walkable neighborhoods" prized by sustainability planners in Portland and elsewhere. Stepwise analysis of variables revealed

\footnotetext{
${ }^{1}$ Values range from -1 to 1 . A high score represents a block group in which most households are in the middleincome range of $\$ 35 \mathrm{k}$ to $\$ 100 \mathrm{k}$, and the share of households above and below this range was evenly distributed. Conversely, a low score represents few families in the middle household income category and disproportion in either the high or low end. Whether the low score represented a disproportionate wealth or poverty was less of a concern than the presence of middle income households and even integration of high and low income households. In the Portland metropolitan region, approximately $29 \%$ of households are in the lower group, $46 \%$ in the middle and $24 \%$ in the upper group. Nationally, these are more evenly distributed at 25\%, 50\%, and 25\%, respectively.
} 
significant collinearity in the Vancouver data, leading us to remove percent ownership and economic integration from the model.

\subsubsection{Mail survey}

To validate our spatial analysis and to better understand the characteristics and motivations of households engaging in food production, we then conducted a mail survey of SFR households in November 2013. We randomly selected household addresses from two populations. The first population was comprised of a random sample of 1,000 SFR households identified through our mapping and divided into three geographical regions for comparison: Inner Portland (400 households), East Portland (300 households), and Vancouver (300 households). A second sample of 600 households was randomly selected from the general population Portland and Vancouver to test for undercount, weighting each region by postal (ZIP) code to ensure a geographically representative population.

The 34-question survey was sent by mail in English and Spanish with an introductory letter requesting that the household member regularly involved in grocery shopping and/or gardening complete the survey. We also gave recipients the option to complete the survey online. After two weeks, we sent a reminder postcard to all recipients who had not yet responded. The overall response rate from the mapped population was 33\%, with some geographic variation: $42 \%$ responded from Inner Portland, 30\% responded from East Portland, and 25\% responded from Vancouver. The overall response rate from the general population was $22 \%$, also with considerable geographic variability: 34\% responded in Inner Portland, 16\% in East Portland, and $15 \%$ in Vancouver. Given margins of error ranging from 6 to $9 \%$, we consider results to be representative of the survey respondents rather than generalizable to the overall population.

We compared GIS data to mapped population surveys to determine false positives and to the general population surveys to determine undercount. We aggregated all surveys from respondents with gardens to create a gardening population dataset $(\mathrm{N}=374)$, and used JMP software to calculate descriptive statistics, grouped by geography, income, education level, gender, and age, and to conduct Pearson's $\chi^{2}$ tests to identify statistically significant relationships between these groups and other categorical and ordinal responses.

\section{Results}

\subsection{Mapping}

Overall, we identified more than 3,000 gardens in Portland, totaling 6.5 ha and nearly 500 gardens in Vancouver totaling 2.0 ha (see Table 4 and Figure 4). More than three times as many gardens were located in Inner Portland as in East Portland, roughly proportionate to the density of tax lots. Gardens in East Portland were 41\% larger on average, proportionate to the larger average potential cultivable area. Far fewer of these gardens, however, were located in front yards in East Portland (10.7\%), as compared to Inner Portland (24.8\%). Vancouver gardens were nearly twice as large as those in Inner Portland. 
Table 4. Gardens on single-family residential (SFR) tax lots in Portland, OR and Vancouver, WA identified via visual identification

\begin{tabular}{clllllllll}
\hline City & $\begin{array}{l}\text { SFR } \\
\text { tax lots }\end{array}$ & $\begin{array}{l}\text { SFR tax } \\
\text { lots w/ } \\
\text { gardens }\end{array}$ & $\begin{array}{l}\text { Front } \\
\text { yard }^{\text {a }}\end{array}$ & $\begin{array}{l}\text { Side } \\
\text { or } \\
\text { back } \\
\text { yard }^{\text {a }}\end{array}$ & $\begin{array}{l}\text { Percent } \\
\text { of SFR } \\
\text { tax lots }\end{array}$ & $\begin{array}{l}\text { Total } \\
\text { area }\end{array}$ & $\begin{array}{l}\text { Mean } \\
\text { garden } \\
\text { area }\end{array}$ & $\begin{array}{l}\text { Mean } \\
\text { proportion } \\
\text { of parcel } \\
\text { under } \\
\text { cultivation } \\
\%\end{array}$ & $\begin{array}{l}\text { Mean } \\
\text { potential } \\
\text { cultivable } \\
\text { area of SFR } \\
\text { tax lots with } \\
\text { gardens } \\
\mathrm{m}^{2}\end{array}$ \\
\hline Portland & 193,344 & 3,022 & 23.2 & 83.3 & 1.6 & 6.5 & 22.3 & 3.8 & 650.2 \\
Inner & 152,529 & 2,223 & 24.8 & 76.2 & 1.5 & 4.5 & 20.4 & 3.9 & 583.2 \\
East & 42,807 & 668 & 10.7 & 90.1 & 1.6 & 1.9 & 28.7 & 3.7 & 872.9 \\
Vancouver & 48,204 & 499 & 10.9 & 91.5 & 1.0 & 2.0 & 39.7 & 2.6 & 1007.8 \\
\hline
\end{tabular}

* some tax lots have both front and side or backyard gardens

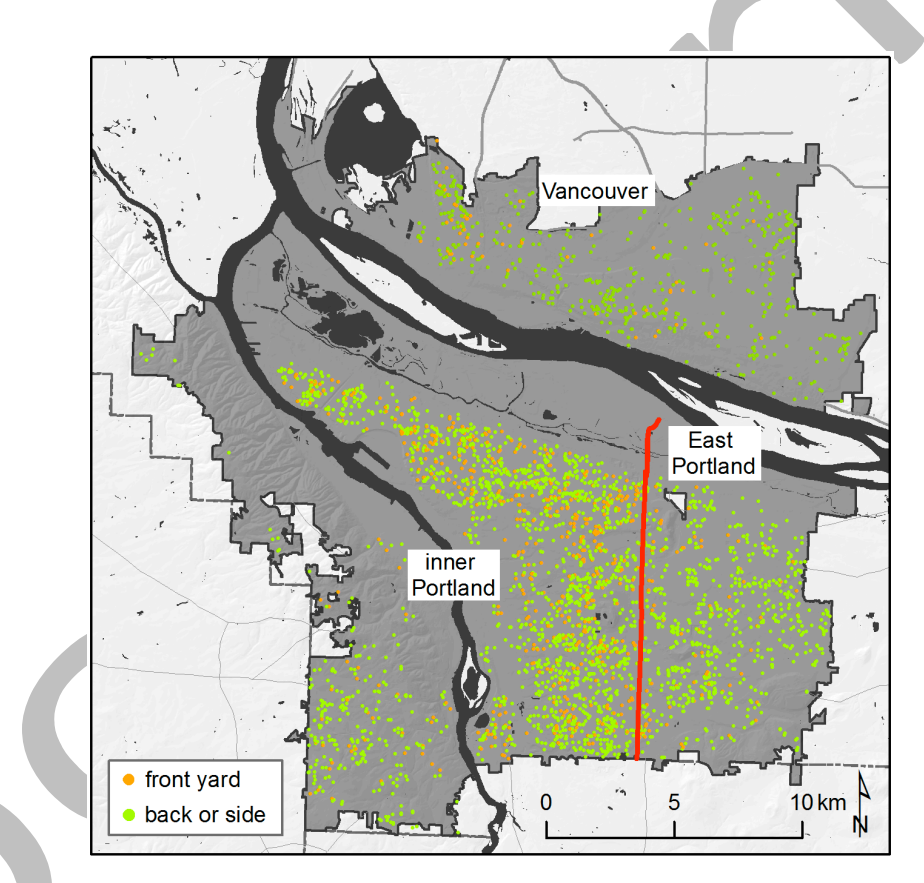

Figure 4. Residential gardens in Portland, OR and Vancouver, WA. Most gardens are back or side yard gardens (green). Front yard gardens (orange) are more common in Inner Portland than in East Portland and Vancouver.

The returned surveys indicated that $5.5 \%$ of the gardens we identified were false positives. Groundtruthing of the sub-sample of seven block groups, however, revealed 100\% accuracy of classification of front yard gardens (i.e., no false positives). Regression revealed no significant relationship between garden undercount and canopy cover $\left(R^{2}=0.11, p=0.449\right)$, suggesting that variance may instead be attributed to a suite of factors, including variable rates of new garden construction across the city. In one Inner Portland block group, for example, as many as fourteen front yard gardens had been constructed during the elapsed time (one year) between when the aerial images were taken, and the gardens mapped and groundtruthed. 


\subsection{Spatial analysis}

\subsubsection{Block group clustering}

At the block group level, clear spatial patterns emerge. In Portland, gardens are concentrated in Inner Portland, between the Willamette River and East Portland (see Figure 5a), while front yard gardens are concentrated in block groups adjacent and slightly to the south and west of the two largest clusters of gardens (see Figure 7b). Notably, there is a relative absence of front yard gardens in East Portland. Garden concentrations in Vancouver do not follow such a clear pattern: while gardens are primarily concentrated in the neighborhoods closest to the downtown core (see Figure 7c), there are several other clusters throughout the city, both in newer, denser areas, and older, less dense suburbia. Concentrations of front yard gardens in Vancouver are similarly, dispersed throughout the city, with few areas of lower than average concentrations (Figure $7 \mathrm{~d}$ ).

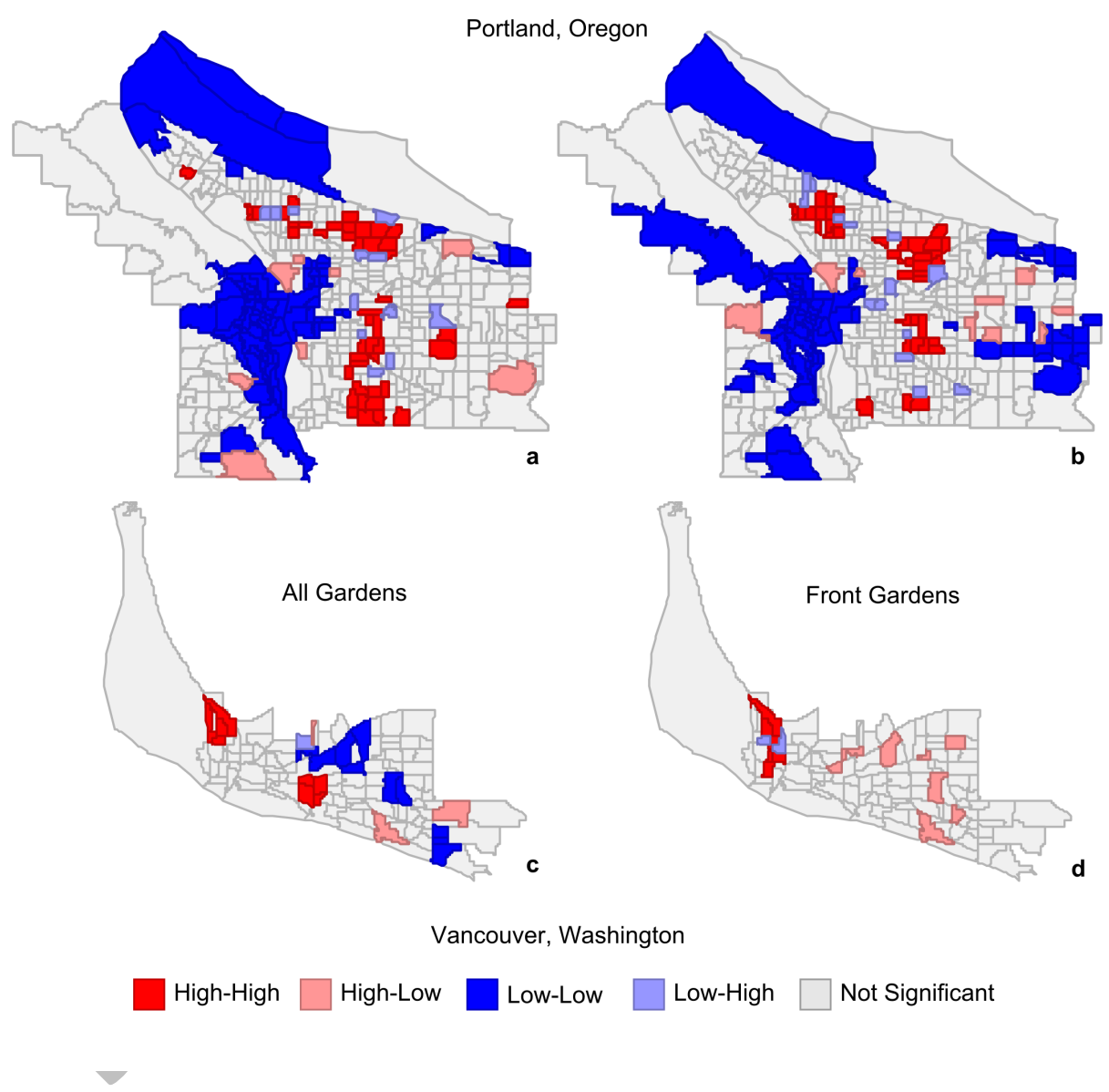

Figure 5. Univariate Local Moran's I (LMI) of all residential gardens (left, a and c) and front yard gardens only (right, $b$ and d) by block group (LQ) in Portland, OR (top, a and b) and Vancouver, WA (bottom, $c$ and d). Note that the two cities have been analyzed separately. High-high block groups have high LQs and neighboring blocks groups have high LQs. High-low block groups have high LQs and neighboring block groups have low LQs. Low-high block groups have low LQs and neighboring block groups have high LQs. Finally, low-low block groups have low LQs and neighboring block groups have low LQs. LMI values for Portland all gardens (a) and front gardens (b) were 0.401 and 0.286 , respectively. LMI values for Vancouver all gardens (c) and front gardens (d) were 0.182 and 0.278 , respectively. Each LMI (a, b, c, and d) had a pseudo-p value of $\mathrm{p}<0.01$. 


\subsubsection{Spatial regression}

Given the significant spatial autocorrelation of the gardens, spatial regression models were more robust than OLS models. In Portland (see Table 5), the spatial lag model revealed significant positive relationships between garden concentrations and economic integration $(p<0.05)$, and the log of the non-white population $(p<0.10)$. Front yard gardens, however, were more strongly associated with economic integration $(\mathrm{p}<0.05)$ and a high Walk Score $(\mathrm{p}<0.05)$ than with home ownership ( $<<0.10$ ), while side/backyard gardens only correlated with the nonwhite population $(p<0.05)$. In Vancouver (see Table 6$)$ there was a significant negative relationship between front gardens and the log of the share of non-white population $(\mathrm{p}<0.10)$, and a positive relationship between front yard gardens and Walk Score $(p<0.05)$. Unlike Portland results, however, these variables did not significantly explain concentration of gardens or backyard gardens in Vancouver.

Table 5. Comparison of ordinary least squares (OLS) and spatial lag regression coefficients of garden location quotients (LQ) and select socioeconomic variables in Portland, Oregon.

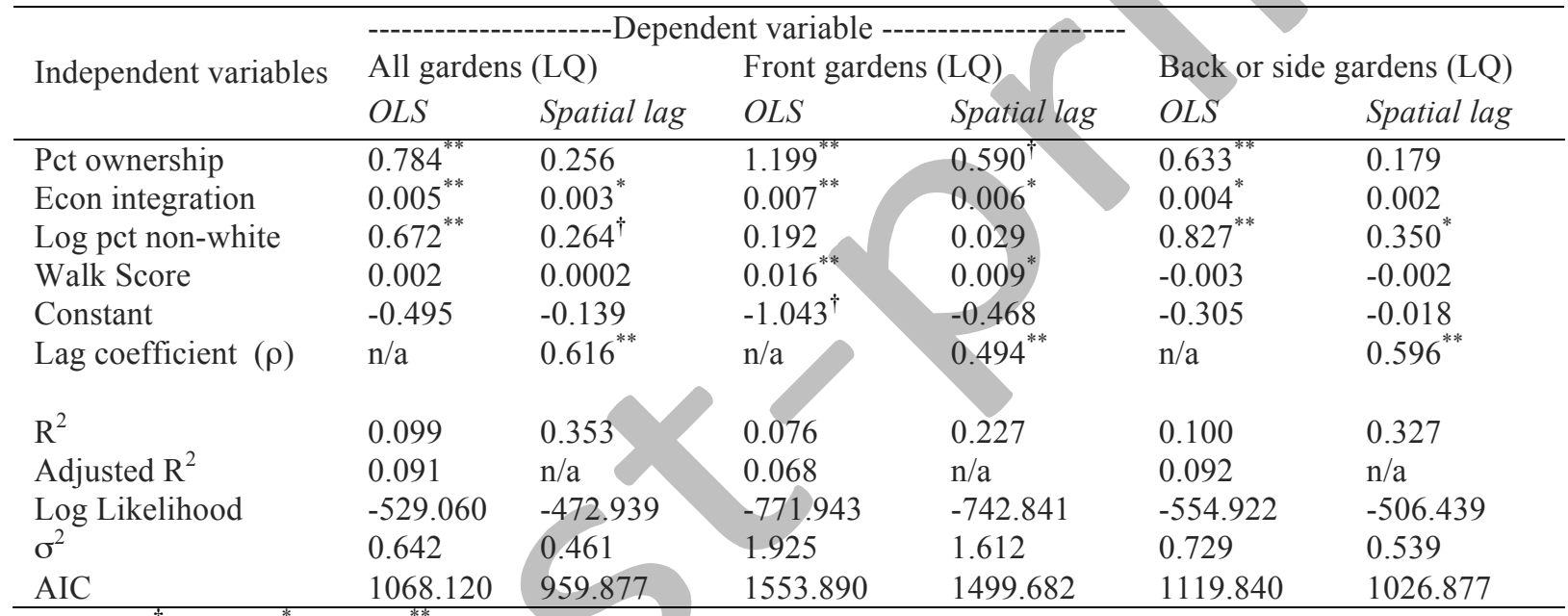

$\mathrm{N}=442 ;{ }^{\dagger} \mathrm{p}<0.10 ;{ }^{*} \mathrm{p}<0.05 ;{ }^{* *} \mathrm{p}<0.01 ; \mathrm{AIC}=$ Akaike information criterion

Table 6. Comparison of ordinary least squares (OLS) and spatial lag regression coefficients of garden location quotients (LQ) and select socioeconomic variables in Vancouver, Washington.

\begin{tabular}{|c|c|c|c|c|c|c|}
\hline \multirow{2}{*}{ Independent variables } & \multicolumn{2}{|c|}{ All gardens (LQ) } & \multicolumn{2}{|c|}{ Front gardens (LQ) } & \multicolumn{2}{|c|}{ Back or side gardens (LQ) } \\
\hline & $O L S$ & Spatial lag & $O L S$ & Spatial lag & $O L S$ & Spatial lag \\
\hline Log pct non-white & -1.299 & -0.811 & $-0.495^{* *}$ & $-0.292^{\dagger}$ & -0.91 & -0.567 \\
\hline Walk Score & -0.003 & -0.003 & $0.003^{* *}$ & $0.002^{*}$ & -0.006 & -0.005 \\
\hline Constant & $2.924^{* *}$ & 1.886 & $0.679^{* *}$ & $0.381^{\dagger}$ & $2.403^{*}$ & $1.594^{\dagger}$ \\
\hline Lag coefficient $(\rho)$ & $\mathrm{n} / \mathrm{a}$ & $0.374^{* *}$ & $\mathrm{n} / \mathrm{a}$ & $0.476^{* *}$ & $\mathrm{n} / \mathrm{a}$ & $0.349^{* *}$ \\
\hline $\mathrm{R}^{2}$ & 0.029 & 0.115 & 0.102 & 0.238 & 0.028 & 0.102 \\
\hline Adjusted $\mathrm{R}^{2}$ & 0.012 & $\mathrm{n} / \mathrm{a}$ & 0.086 & $\mathrm{n} / \mathrm{a}$ & 0.011 & $\mathrm{n} / \mathrm{a}$ \\
\hline Log Likelihood & -181.571 & -177.819 & -2.522 & 4.300 & -175.610 & -172.438 \\
\hline$\sigma^{2}$ & 1.376 & 1.221 & 0.063 & 0.052 & 1.241 & 1.117 \\
\hline AIC & 369.142 & 363.637 & 11.0441 & 0.478 & 357.221 & 352.876 \\
\hline
\end{tabular}

$\mathrm{N}=116 ;{ }^{\dagger} \mathrm{p}<0.10 ;{ }^{*} \mathrm{p}<0.05 ;{ }^{* *} \mathrm{p}<0.01 ; \mathrm{AIC}=$ Akaike information criterion 


\subsection{Survey results}

\subsubsection{Demographic and socioeconomic characteristics of gardeners}

Survey respondents in all geographic zones were disproportionately white and female, and older and more highly educated than the overall population (see Table 7 and Figure 6). Front yard gardeners, in particular, had higher levels of educational attainment: $70 \%$ had undergraduate or graduate degrees compared to $58 \%$ of those with only backyard gardens (58\%). Income differentiation was markedly different across geographic areas (see Figure 7). In Inner Portland, most surveyed gardeners had high annual incomes $(>\$ 75,000)$, while there were few low-income $(<\$ 35,000)$ gardeners, despite a nearly equal share of low- and high-income households among the overall population. In East Portland there were more low-income gardeners, and thus disproportionately represented compared to the overall population, a trend reverse to that of Inner Portland. Home ownership was strikingly high among respondents from both cities (89 to $90 \%$ ) as compared to general population (50 to 55\%). In Vancouver, the results were similar, but with a more equal share of medium- and high-income gardeners and disproportionately small number of low-income gardeners.

Table 7. Comparison of select socio-economic characteristics of survey respondents to population

\begin{tabular}{|c|c|c|c|c|c|c|}
\hline & \multicolumn{2}{|c|}{ Inner Portland } & \multicolumn{2}{|c|}{ East Portland } & \multicolumn{2}{|l|}{ Vancouver } \\
\hline & Survey & Census & Survey & Census & Survey & Census \\
\hline Median age & 43.5 & 36 & 55 & 39 & 56 & 37 \\
\hline$\%$ female & 73.4 & 50.7 & 72.0 & 50.8 & 73.2 & 50.9 \\
\hline$\%$ white & 90.4 & 76.9 & 84.5 & 61.2 & 91.6 & 90.1 \\
\hline$\%$ own home & 89.3 & 54.0 & 89.0 & 55.2 & 90.4 & 50.2 \\
\hline Median HH income & $\begin{array}{l}\$ 75,000 \text { to } \\
\$ 99,999\end{array}$ & & $\begin{array}{l}\$ 35,000 \mathrm{t} \\
\$ 49,999\end{array}$ & $\$ 44,732$ & $\begin{array}{l}\$ 50,000 \text { to } \\
\$ 74,999\end{array}$ & $\$ 49,271$ \\
\hline $\begin{array}{l}\% \text { bachelor's or } \\
\text { graduate degree }\end{array}$ & 76.1 & & 39.8 & 18.6 & 51.8 & 23.7 \\
\hline
\end{tabular}

While most female respondents in Vancouver were between 50 and 70 years of age, most respondents in Portland were in either their sixties or thirties. Patterns among male respondents mirrored those of East Portland and Vancouver. In Inner Portland, more respondents (male and female alike) were younger (age 30 to 39) than elsewhere. At first glance, one might assume that these two bulges in the distribution map correspond to the current wave of UA (since 2005) and its previous peak in popularity during the 1970s and early 1980s (Bassett, 1981; Lawson, 2005). However, the relationship between age and the number of years gardening is not particularly strong $\left(\mathrm{R}^{2}=0.40\right)$; only about one-quarter ( $24 \%$ of female and $26 \%$ of male) of respondents over the age of 50 began gardening between 1970 and 1985, while roughly one-third (33\% of female and $35 \%$ of male) of the same age group has only gardened since 2005 . 


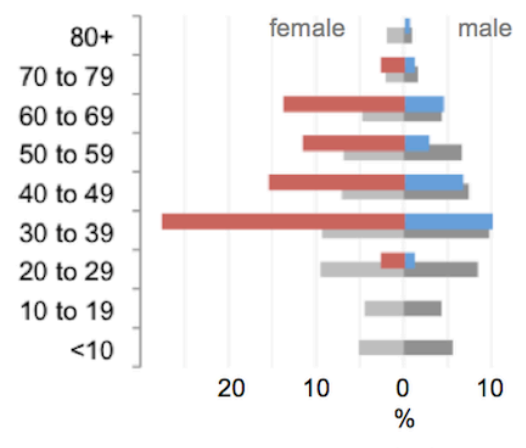

Inner Portland

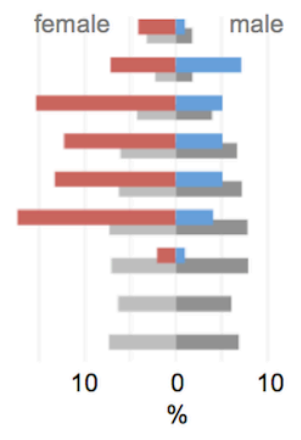

East Portland

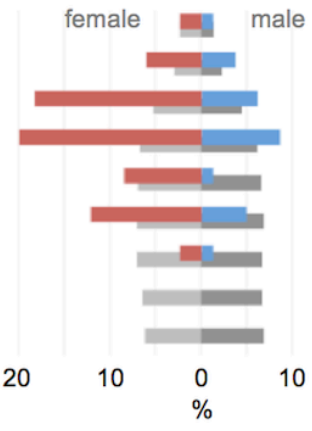

Vancouver

Figure 6. Age distribution of survey respondents by gender $(\mathrm{red}=$ female, blue $=$ male $)$ compared to total population by geography (light gray $=$ female, dark gray $=$ male).
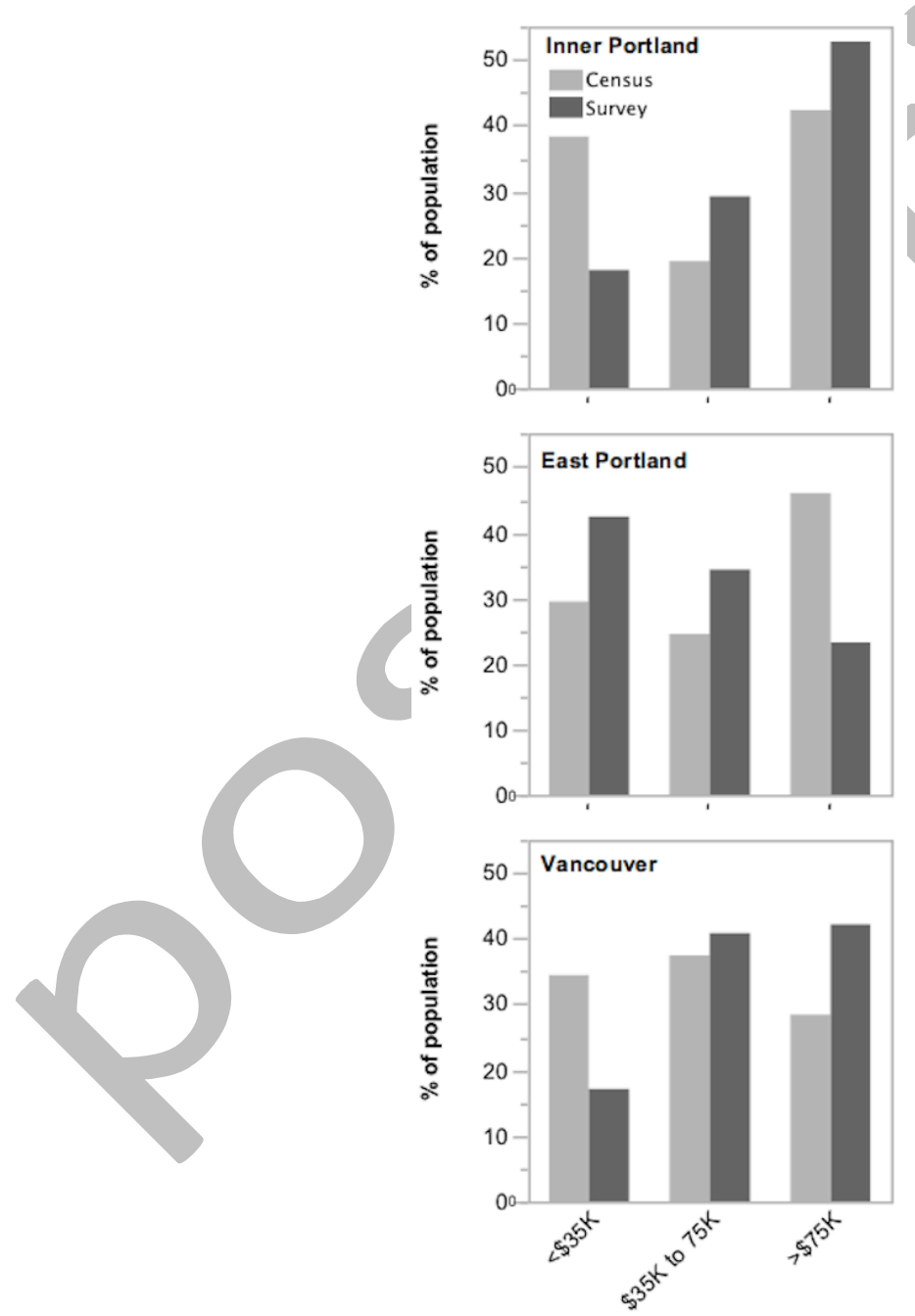

MHI (\%)

Figure 7. Income distribution of survey respondents compared to median household income (MHI) of overall population by geography. 


\subsubsection{Garden size, location, and contribution to consumption}

Median garden size was the same (9.3 to $\left.46.5 \mathrm{~m}^{2}\right)$ across all groups. While most respondents had gardens in this range (with little geographic variation), more respondents in East Portland and Vancouver had only a few plants (see Table 8). As the spatial data also reveal, the location of gardens (i.e., front versus side or backyard) differed geographically, with front yard gardens much more common in Inner Portland than in East Portland or Vancouver.

Table 8. Location of residential gardens in Portland, OR and Vancouver, WA as assessed by mail survey

\begin{tabular}{|c|c|c|c|c|c|c|c|c|}
\hline \multirow{3}{*}{ City } & \multirow{3}{*}{$\begin{array}{l}\text { Surveys } \\
\mathrm{N} \\
\end{array}$} & \multicolumn{2}{|c|}{ Garden location } & \multicolumn{5}{|c|}{ 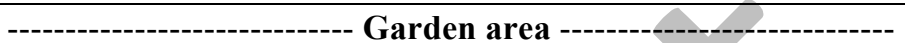 } \\
\hline & & $\begin{array}{l}\text { Front } \\
\text { yard }\end{array}$ & $\begin{array}{l}\text { Side or } \\
\text { backyard }\end{array}$ & $\begin{array}{l}\text { Only a few } \\
\text { plants }\end{array}$ & $\begin{array}{l}0.93 \text { to } 9.3 \\
\mathrm{~m}^{2}\end{array}$ & $\begin{array}{l}9.3 \text { to } 46.5 \\
\mathrm{~m}^{2}\end{array}$ & $\begin{array}{l}46.5 \text { to } 92.9 \\
\mathrm{~m}^{2}\end{array}$ & $\begin{array}{l}>92.9 \\
\mathrm{~m}^{2}\end{array}$ \\
\hline & & & & & of responde & & 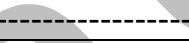 & ----- \\
\hline Portland & 284 & 27.5 & 91.1 & 9.3 & 39.5 & 37.0 & 8.7 & 5.5 \\
\hline Inner & 188 & 30.3 & 89.4 & 6.9 & 41.5 & 36.7 & 8.5 & 5.9 \\
\hline East & 96 & 22.3 & 94.2 & 13.6 & 35.0 & 36. & 8.7 & 4.9 \\
\hline Vancouver & 83 & 24.1 & 92.8 & 10.8 & 33.7 & 39.8 & 10.8 & 4.8 \\
\hline
\end{tabular}

Overall, home gardens provided less than $10 \%$ of total vegetable needs during the growing season for $18 \%$ of respondents. Further, $30 \%$ reported that their gardens fulfilled 10 to $25 \%$ of vegetable consumption needs, while $22 \%$ reported a quarter to half of total needs, and the remaining $30 \%$ were able to produce more than $50 \%$ of vegetables consumed during the growing season. Income had a significant impact on consumption, however $\left(\chi^{2}=15.88, p<0.05\right): 38 \%$ of the lowest income group reported meeting all to almost all ( 75 to $100 \%$ ) of vegetable needs during growing season, while only 11 to $16 \%$ of other groups harvested this much of their overall consumption from their gardens. This may be explained in part by significant differences in vegetable consumption between income groups $\left(\chi^{2}=35.49, \mathrm{p}<0.05\right)$. The lowest income group ( $\$ 0$ to 14,999 per year) reported lower overall vegetable consumption: almost half $(48 \%)$ reported eating vegetables a few times per week, but not every day. Roughly a third (31 to 33\%) of households earning $\$ 15,000$ to 49,999 reported this same rate of consumption, whereas the majority ( 79 to $83 \%$ ) of respondents with household incomes over $\$ 50,000$ consumed vegetables at least once per day.

\subsubsection{Considerations and motivations of gardeners}

Most respondents reported that freshness (86\%) and eating healthy $(73 \%)$ were "very important" considerations when procuring vegetables for their households. Locally grown (55\%) and price/affordability (49\%) were "somewhat important", whereas a vegetarian/vegan diet was "not at all" a consideration for $62 \%$ of respondents (see Appendix A.1). When asked why they produce food themselves, most respondents (79\%) indicated that having fresh, nutritious produce was a very important reason, while $97 \%$ reported that earning money was not at all a reason (see Appendix A.2). Other somewhat or very important reasons to produce were: to live in an

\footnotetext{
${ }^{2}$ We did not ask respondents to measure the actual amount consumed, as it would have been unrealistic to ask respondents to do so. Furthermore, we were more concerned with the extent to which garden vegetables met the individuals' perceived needs rather than an established average recommended consumption threshold.
} 
environmentally sustainable way (84\%); to relax or unwind (72\%); and to be more self-sufficient $(71 \%)$.

Many of these motivations and considerations, however, differ along income, educational, class, and geographic lines (see Table 9). There was a significant difference between income groups regarding important considerations when purchasing vegetables. Price/affordability was more important for low-income respondents, while organic/pesticide-free was more important for higher-income groups. Educational attainment was positively associated with other considerations: locally grown; organic/pesticide-free; and labor practices/farmworker conditions. Given the higher educational attainment in Inner Portland, these translated into significant geographic differences in terms of the importance of organic/pesticide-free and labor practices/farmworker conditions.

Table 9. Considerations and motivations of respondents by: geography (Inner Portland, East Portland, or Vancouver), gender (male or female), age $(<50$ or $50+$ ), education (no secondary education, some undergraduate education, or graduate degree), and income $(<\$ 35 \mathrm{~K}, \$ 35 \mathrm{~K}$ to $75 \mathrm{~K}$, or $>\$ 75 \mathrm{~K})$.

\begin{tabular}{|c|c|c|c|c|c|c|c|c|c|c|}
\hline \multirow[b]{2}{*}{$\begin{array}{l}\text { How important to you are the following } \\
\text { considerations when you purchase } \\
\text { vegetables for your household? }\end{array}$} & \multicolumn{2}{|c|}{$\begin{array}{l}\text { Geography } \\
\chi^{2}\end{array}$} & \multicolumn{2}{|c|}{$\begin{array}{l}\text { Gender } \\
\chi^{2}\end{array}$} & $\begin{array}{l}\text { Age } \\
\chi^{2}\end{array}$ & \multicolumn{3}{|c|}{$\begin{array}{l}\text { Educational } \\
\text { attainment }\end{array}$} & \multicolumn{2}{|c|}{$\begin{array}{l}\text { Household } \\
\text { income } \\
\chi^{2} \\
\end{array}$} \\
\hline & & & & & & & & & & \\
\hline Price / affordability & 7.84 & & 9.46 & * & 7.10 & $\dagger$ & 15.32 & $\dagger$ & 32.22 & $* * *$ \\
\hline Freshness & 6.99 & & 1.11 & & 8.80 & * & 14.99 & $\dagger$ & 6.40 & \\
\hline Locally grown & 8.94 & & 0.91 & 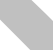 & 1.90 & & 0.07 & $\dagger$ & 7.27 & \\
\hline Organic or pesticide free & 15.63 & * & 2.74 & & 4.93 & & 44.81 & $* * *$ & 15.46 & * \\
\hline Eating healthy & 5.67 & & 7.89 & * & 0.19 & & 21.94 & ** & 6.80 & \\
\hline Vegetarian/vegan diet & 1.42 & & 6.38 & $\dagger$ & 6.28 & $\dagger$ & 7.37 & & 5.77 & \\
\hline Labor practices / farmworker conditions & 19.25 & $* *$ & 5.78 & & 6.81 & $\dagger$ & 34.56 & $* *$ & 9.96 & \\
\hline $\begin{array}{l}\text { How important are the following reasons } \\
\text { for why your household produces food? }\end{array}$ & & & & & & & & & & \\
\hline To earn money & 4.85 & & 0.51 & & 2.19 & & 6.64 & & 7.72 & \\
\hline To save money & 9.59 & & 2.41 & & 9.95 & * & 13.08 & & 27.12 & $* * *$ \\
\hline To barter / trade without using money & 6.61 & & 1.86 & & 5.46 & & 5.87 & & 9.28 & \\
\hline To be self-sufficient & 12.57 & $\dagger$ & 4.15 & $\dagger$ & 17.92 & ** & 29.21 & ** & 14.02 & * \\
\hline To have enough food to eat & 10.99 & $\dagger$ & 7.39 & $\dagger$ & 5.06 & & 25.44 & $* *$ & 30.71 & $* * *$ \\
\hline $\begin{array}{l}\text { To build community / connect with } \\
\text { friends or neighbors }\end{array}$ & 8.16 & & 1.85 & & 15.02 & ** & 11.39 & & 5.43 & \\
\hline To relax or unwind & 7.12 & & 0.89 & & 6.30 & $\dagger$ & 12.73 & & 4.36 & \\
\hline To make my yard look nice & 7.73 & & 1.776 & & 7.66 & $\dagger$ & 11.72 & & 8.15 & \\
\hline To have fresh, nutritious produce & 7.78 & & 5.98 & & 4.01 & & 19.53 & $*$ & 12.99 & $*$ \\
\hline $\begin{array}{l}\text { To live in a more environmentally } \\
\text { sustainable way }\end{array}$ & 12.56 & $\dagger$ & 2.52 & & 13.98 & $* *$ & 39.68 & $* * *$ & 13.50 & * \\
\hline Because I'm concerned about food safety & 7.05 & & 5.34 & & 1.94 & & 12.58 & & 9.37 & \\
\hline To educate myself or others & 10.04 & & 0.77 & & 9.37 & * & 16.38 & $\dagger$ & 15.99 & * \\
\hline $\mathrm{N}$ & 374 & & 366 & & 366 & & 368 & & 353 & \\
\hline $\mathrm{df}$ & 6 & & 3 & & 3 & & 9 & & 6 & \\
\hline
\end{tabular}

Significance as tested by Pearson's $\chi^{2}: \dagger \mathrm{p}<0.10 ;{ }^{*} \mathrm{p}<0.05 ;{ }^{* *} \mathrm{p}<0.01 ;{ }^{* * *} \mathrm{p}<0.001$ 
Education and income levels also marked differences in what motivates respondents to produce food. To be self-sufficient, to live in an environmentally sustainable way, and to have fresh, nutritious produce were all more important concerns for respondents with higher levels of education and income. While nearly half of respondents said that having enough food to eat was not at all a reason for producing food (see Appendix A.2), responses were inversely related to income and educational attainment. Given the higher number of low-income respondents in East Portland, engaging in UA for such concerns over food security was also related to geography. Income levels also correlated negatively with concern over saving money. Low-income residents also disproportionately cited "to educate myself or others" as a motivation to produce food.

Some considerations and motivations also differed significantly by gender and age. To have enough food to eat was a more important motivation among female respondents, while more women reported that being self-sufficient was not at all important. Women also rated eating healthy and price/affordability as more important considerations when purchasing vegetables than did male respondents. Freshness was more of an important consideration for respondents over 50, while price/affordability was more important for those under 50 . More respondents over 50 responded that self-sufficiency was not at all a reason for their engagement in food production, nor was building community. There were also significant differences between age groups in terms of motivation to live in a more environmentally sustainable way, however. Among those under 50, 58\% found this to be a "very important" reason, compared to $49 \%$ of those over 50 . Similarly, $8.2 \%$ of respondents over 50 said this reason was "not at all important, compared to only $1.6 \%$ of those under 50 . A vegetarian/vegan diet was also less important for respondents over 50 .

\section{Discussion}

Results from both the mapping and survey expose the uneven socio-spatial distribution of residential gardening in metropolitan Portland. Supporting previous studies of gardens and other forms of green infrastructure, our results reveal that spatial concentrations of residential gardens correlate positively with a suite of socioeconomic indicators, the most important of which may be home ownership. Percent ownership was the most significant predictor of garden concentrations according to our spatial regression, and 89 to $90 \%$ of those surveyed reported owning their homes. Schupp and Sharp (2012) reported similar rates of home ownership among home gardeners in Ohio, Comstock et al. (2010) reported 69\% in their Denver survey, and Smith et al. (2013) found that home ownership was the best indicator of home garden presence in Madison, Wisconsin. Other studies have found a similar relationship between home ownership and other forms of vegetation (Kinzig et al., 2005; Kirkpatrick, Daniels, \& Zagorski, 2007; Martin et al., 2004). This is unsurprising, as people may be more inclined to invest their time and effort into building a garden when there is more security of tenure. Indeed, in our survey, $63 \%$ of non-gardening renters stated that they would garden if they owned their home. Income level (which generally co-varies with home ownership) also had a significant statistical relationship to both the spatial distribution of residential UA and the motivations driving it. In our study, UA concentrations strongly correlated with middle- and mixed-income neighborhoods. Similarly, Smith et al. (2013) found garden concentrations to be highest in the third income quartile. Residential gardeners in our study and others thus appear to be somewhat more affluent and educated than those involved in community gardens (Drake \& Lawson, 2014; Kortright \& 
Wakefield, 2011; Pourias et al., 2015), which provide access to growing to those who may not have adequate space of their own where they live.

But rates of single-family home ownership and income stratification alone cannot fully explain UA's socio-spatial variation; rather, we should understand the significance of these variables within a broader context of neighborhood change. Indeed, the socio-spatial differentiation of UA in Portland maps onto larger-scale patterns of reinvestment in the urban core and related displacement of poverty to the periphery, a process occurring in cities across the country (Hanlon, 2009; Lee \& Leigh, 2007). Saddled with debt and a dwindling tax base in the wake of deindustrialization and suburbanization (Massey \& Denton, 1993; Sugrue, 2005), municipal governments adopted an entrepreneurial logic to attract development (Hackworth, 2007; Harvey, 1989; N. Smith, 2002). Over the past couple of decades, a growing "rent gap" between actual market prices and unrealized market potential has attracted reinvestment in the core. Such investment - in transit, housing, parks, and retail - has been justified as necessary to attract the young, college-educated (YCE) "creative class" (Peck, 2005; Scott, 2006). New construction and the influx of this relatively affluent, mostly white population have, in turn, fueled the displacement of lower-income residents, both directly by causing housing prices to rise, and indirectly through the transformation of the socio-cultural landscape, e.g., the loss of culturally relevant stores, minority-owned businesses, churches, and homes (Davidson \& Lees, 2009).

These dynamics are especially visible in Portland. Under the banner of "walkability" and "livability", municipal, county, and regional (Metro) governments have invested heavily in public transit (including light rail and streetcars), bike lanes, mixed-use neighborhoods, and high-density in-fill housing (Ozawa, 2004). Much of this construction has occurred in devalued working class neighborhoods or industrial districts where the rent gap was large enough to attract investors. In the early 1990s, for example, the city launched an economic development initiative in the city's historically low-income African American district in inner Northeast Portland. Since then, this area of Portland has seen dramatic transformations. New businesses cater to a growing (mostly white) clientele of YCEs, old housing stock has been renovated and new condos constructed, and much of the area's largely low-income African American population has been displaced to East Portland and other suburbs (Gibson, 2007; Goodling et al., 2015). Portland now has a disproportionately high YCE population, a demographic that continues to relocate to the Portland metro area (Cortright, 2014; Jurjevich \& Schrock, 2012).

Similar to other studies (Comstock et al., 2010; National Gardening Association, 2014) our survey respondents were mostly white, highly educated, and affluent (Table 7 and Figure 7), thus diverging somewhat from the census population. In Inner Portland, many were also young. Among gardeners nationwide, this demographic is growing; the National Gardening Association (2014) reports that $31 \%$ of gardeners in the US are between 18 and 34 years old. The increasingly YCE face of urban gardeners has stoked concerns in Portland and nationwide that UA contributes to processes of gentrification and displacement by making spaces more amenable to higher-end investment (Crouch, 2012; Markham, 2014). Our spatial data reveal that the highest concentrations of residential gardens can indeed be found in census block groups east of the Willamette River, particularly in those census tracts identified by a City of Portland study as in early to mid-stages of gentrification (Bates, 2013). These are precisely the sorts of neighborhoods where the influx of middle-income residents is leading to an economic integration index closer to 1 and where Walk Scores are higher. Both are significant variables in our model. 
But rather than solely a function of a growing concentration of YCEs in the urban core, we must also consider the growing interest in gardening and environmental sustainability more broadly, even among long-time residents. As the age distribution of respondents suggests, female gardeners in Portland primarily fall into two age groups: those in their mid-60s and those in their mid-30s to mid-40s. One-third of the older respondents actually only began gardening in the past decade, indicating their relatively new interest in UA. Moreover, sustainability and environmental concerns motivate many of these gardeners, supporting the recent findings of other researchers (Dobernig \& Stagl, 2015; Schupp \& Sharp, 2012). What our study shows in more detail, however, is that these environmental values resonate with more affluent and more highly educated gardeners.

Correlated with education and income, such values appear also to be reinforced through spatial clustering. The "spatial contagion" or clustering of front gardens, in particular, is especially illustrative of the spatial agglomeration of tastes, values, and landscape management practices (Hunter \& Brown, 2012). Visible to neighbors and passersby, a food garden in the front yard serves as a marker of environmental consciousness and adherence to sustainable practices increasingly supported by local policy initiatives that directly or indirectly incentivize the removal of lawns such, e.g. the Backyard Habitat Certification Program, Native Plant MiniGrants, Metro Lawn and Garden coupons, the Stormwater Discount Program, and several governmental online information portals. ${ }^{3}$ Transformation of one's lawn into a garden thus serves a performative function, signaling a household's adherence to this new set of values. In Inner Portland, where both front and back gardens are clustered, 91\% of front yard gardeners and $85 \%$ of backyard gardeners responded that "to live in a more environmentally sustainable way" was a "somewhat" or "very important" motivation. Similarly, in suburban Vancouver, where respondents were considerably more affluent and highly educated than the overall population, $94 \%$ of front yard gardeners cited the importance of environmental sustainability, versus $74 \%$ of backyard gardeners.

In East Portland, on the other hand, where respondents' incomes were lower than average, but educational attainment higher, there was no significant clustering of gardens. Only $70 \%$ of front yard and $71 \%$ of backyard gardeners cited environmental sustainability as an important motivation, significantly lower than in Inner Portland and Vancouver. Traveling around East Portland, one sees many more conventional lawns and far fewer food gardens or landscaping. Indeed, the lawn in East Portland - and in low-income areas, more generally - may have a more conventional valence, particularly in working class neighborhoods with large immigrant and non-white populations. Rather than signaling the embrace of a localized vision of environmental sustainability, replacing the lawn with a garden might constitute a transgression of dominant cultural norms (Naylor, 2012; Robbins, 2007) according to which the lawn serves as a meritocratic signal of having achieved the American Dream (Duncan \& Duncan, 2004; Li, 2011).

Despite the lack of garden clustering in East Portland, survey responses nevertheless speak to the interrelation between neighborhood change and the emergence of particular agglomerations of motivations. Given the significantly higher percentage of low-income responses, gardening "to have enough to eat" was a more common motivation among East

\footnotetext{
${ }^{3}$ Furthermore, the significant relationship between Walk Score and front yard gardens also points to an agglomeration of environmental values in both cities is likely fostered by a regional commitment to density and walkability via planning goals such as the "20-Minute Neighborhood". One of the goals set by Portland's Climate Action Plan is that $90 \%$ of residents will be able to "easily walk or bicycle to meet all daily, non-work needs" by 2030 (City of Portland \& Multnomah County, 2009, p. 39).
} 
Portland respondents than among those from Inner Portland or Vancouver. Gardening "to have enough to eat" was an important motivation for 55\% of East Portland's front yard gardeners, whereas only 34\% of front yard gardeners in Inner Portland responded this way. Concern over saving money was negatively correlated with income, and households in the lowest income bracket were more likely to garden for reasons of food security, e.g., in order to "have enough to eat", "to save money", or "to be self-sufficient". Similarly, respondents in the lowest income bracket reported that their gardens contributed significantly more to their total vegetable consumption than did respondents at any other income bracket.

These results suggest that in addition to serving as a marker of environmental consciousness, UA has maintained its perennial function as a coping strategy even in the Sustainable City. In the Global South, UA has long served this purpose, providing the poorest strata with food for both subsistence and revenue (Zezza and Tasciotti, 2010). This was historically true in the Global North, as well, with gardens serving as "pockets of resilience" (Barthel et al. 2013) by providing a source of food for urban populations in dire times, and serving as a social "safety valve" to keep restive populations from partaking in food riots (Bassett, 1981; Lawson, 2005; McClintock, 2010). Arguably, UA's skyrocketing popularity today is due not only to a growing environmental consciousness, but also to the recent economic downturn. In the wake of the economic crisis of 2008, seed purchases were at their highest since the last wave of UA in the 1970s; people turned to their gardens to provide a sense of stability, if not an actual food safety net (Tavernise, 2011). Similar to our study, Schupp and Sharp (2012) found a positive relationship between economic hardship and gardening in their statewide study of Ohio, and nationally, the number of low-income households (those earning less than $\$ 35,000$ annually) increased by 38\% between 2009 and 2013 (National Gardening Association, 2014).

In sum, our findings underscore the diversity of motivations for UA and how these are spatially differentiated. More specifically, they suggest that the differential proliferation of UA is due to a more complex relationship between structural processes of disinvestment and reinvestment, gentrification and displacement, and the spatial agglomeration of multiple sets of values and motivations. A commitment to environmental sustainability - fostered by municipal, county, and regional policy - certainly drives many people to garden, but appears to be tied to income and education, as well as to agglomerations of front gardens that signal these environmental values and establish a new spatialized norm. At the same time, demographic shifts related to neighborhood change are also highly spatialized, with affluent, more highly educated populations concentrated in Inner Portland and low-income populations concentrated in East Portland. Together these processes have hewn a highly differentiated landscape of residential food production in the region.

\section{Conclusion}

In this paper, we have described a mixed-methods study of the landscape of residential UA in a major metropolitan area of the United States. A mixed-methods approach provides the benefit of triangulating data, while revealing the limitations to the component methods (Elwood, 2009). The disparity in the number of gardens identified via mapping (1.0 to $1.6 \%$ of households) and the percentage of the overall population of SFR households engaged in gardening as estimated via survey responses $(48.3 \pm 7 \%)$ points to the limitations of using aerial imagery to estimate overall residential food production. Instead, remote sensing may help identify general city-scale spatial patterns and complement other forms of data collection. In our 
study, mapping was an accurate (95\%) means of correctly identifying a garden, but resulted in a significant undercount of the overall number of residential gardens due to the difficulty of classification of aerial imagery in urban settings. Vegetation and building shadows can obscure visibility. Without distinctive identifiers (such as parallel rows or raised beds edges), $1 \mathrm{~m}^{2}$ imagery may not be fine-grained enough to capture small-scale gardens nor the $19.4 \%$ of survey respondents who indicated that they have only a few plants or gardens smaller than $0.93 \mathrm{~m}^{2}$. Previous attempts to quantify UA using remote sensing methods have resulted in similarly low counts in Chicago (Taylor \& Lovell, 2012) and in Bamako and Ouagadougou (van den Berg, Kemeling, \& Roerink, 2001). To compensate, many studies depend on groundtruthing to confirm existence of gardens (Hunter \& Brown, 2012; V. M. Smith et al., 2013). Given labor constraints and the fact that most identified gardens were invisible from the street and located on private property, we were only able to groundtruth a sample of front yard gardens. The fast-growing popularity of UA and the ever-changing urban landscape mean that quantification of UA is a moving target and always out of date.

Consistent with other studies, nearly half of our survey respondents reported engagement in food production of some kind. But surveys risk self-selection bias and consequential overreporting by educated, affluent respondents interested in the suryey topic, as well as undercount of traditionally underrepresented populations, e.g., people of color, immigrants, non-Englishspeaking, and low-income populations, especially given the length of the survey (Bowling, 2005; Groves \& Couper, 1998). In our study, response rates were higher in Inner Portland where educational attainment rates and incomes are higher, suggesting self-selection bias. Although the survey was available in English and Spanish, we did not receive any response to the Spanish survey. Additionally, we potentially undercounted other non-English-speaking groups such as the Russian, Vietnamese, Chinese, and Somali populations in Portland. Future studies should collect a random sample of non-responders (Miller \& Smith, 1983) and/or complement the mail survey with targeted recruitment of participants from underrepresented communities via community-based organizations, churches, non-profits, and other avenues.

Despite these limits to quantifying the total food-producing population, significant sociospatial variation among even this sub-sample of metropolitan Portland's population reveals patterns worthy of attention. Indeed, as municipalities develop and broker strategies for sustainability, resilience, and climate-change adaptation, examining the uneven nature of green infrastructure and practices is crucial. Our assessment reveals that one such practice - residential food production - is distributed in an uneven manner. Our findings suggest that the distribution, scale, and scope of UA varies widely both between and within cities, challenging us to move beyond unitary readings of UA and claims of its inherent merits, and push us to instead consider the situated and relational nature of UA practice within specific geographic contexts. Such a study is thus a necessary precursor to rethinking a blueprint for a more just sustainability that considers how to foster resilient urban food systems in ways that do not entrench socio-spatial inequities.

For urban food policymakers, planners, and program officials, our results suggest the need for sustainability messaging and visioning that is sensitive to a variety of motivations, and that resonates with a diverse population. Residents who grow food as a lifestyle politics shaped by environmental values are likely to be those who will respond to and benefit the most from efforts framed using the conventional language of environmental sustainability. For a city to reach a more representative swath of the population, however, it may need to reframe its goals in new ways. Goodling and Herrington (2015), for example, describe how Portland's Community 
Watershed Stewardship Program (CWSP) recognized that most of their community project grants for green infrastructure were going to neighborhoods with white, affluent, well-educated residents. By reframing the language they used in their media and calls for proposals emphasizing "community" over the environment, for example - CWSP was able to attract and ultimately fund more proposals from low-income communities of color, many in East Portland. In their assessment of community involvement in food systems policymaking in New York City, Cohen and Reynolds (2014) cite the importance of targeted grant funding and grant writing support for underrepresented groups, as well as providing stipends for their participation in policymaking settings.

But perhaps more fundamentally, municipal food policymakers should also recognize the limitations of UA as a tool for urban sustainability and resilience. To avoid falling into what Born and Purcell (2006) call "the local trap" - the idea that local production is inherently better and more sustainable - policymakers must recognize that food systems resilience is not merely a question of local production but depends, rather, on a suite of what Amartya Sen (1983) referred to as a "bundle of entitlements" that enable people to access their needs: e.g. sufficient wages to purchase food; transportation to a job and grocery store; adequate housing; and the skills and knowledge of how to produce and prepare food. Especially important, but increasingly rare given the struggle to maintain access to such entitlements, is simply having enough time to cook, much less grow food (Alkon et al., 2013).

Food systems planning, like the sustainability policies and planning that often shape it, must therefore not only break out of its traditional silos of public health and environmental planning (Pothukuchi, 2009), but also engage seriously with the socioeconomic disparities that undermine access to healthy food not just in times of crisis, but on a daily basis. Cross-cutting policy and planning lenses such as food justice (Gottlieb \& Joshi, 2010; Wekerle, 2004), equity (Corburn, 2009; Krumholz, 1990; Pastor, Benner, \& Matsuoka, 2009), and just sustainability (Agyeman, 2013) are increasingly guiding food systems planners to consider these factors, a hopeful sign that sustainability-minded municipalities are beginning to move in the right direction toward conceiving of and fostering food systems that are resilient in ways that guarantee health, food security, and environmental quality for a more diverse urban population.

\section{Acknowledgements}

The authors wish to thank Emily Becker, Anthony Levenda, and Sara Matijascic for their help with survey implementation and data entry. This research was made possible with the support of a Portland State University (PSU) Faculty Enhancement Grant and a grant from PSU's Institute for Sustainable Solutions. Additionally, a Ciência sem Fronteiras Post-Doctoral Grant from the Federal Government of Brazil facilitated the participation of J.P. Santos and the Toulan School of Urban Studies \& Planning provided tuition support for M. Simpson. Funding sources had no role in the study design; in the collection, analysis and interpretation of data; in the writing of the report; nor in the decision to submit the article for publication. 


\section{Author Biographies}

Nathan McClintock, PhD is an assistant professor in the Toulan School of Urban Studies and Planning at Portland State University. He received his PhD in geography from UC Berkeley in 2011 and MS in crop science/agroecology from North Carolina State University in 2004. His research focuses on urban agriculture, food systems planning, and urban political ecology.

Dillon Mahmoudi is a PhD candidate in urban studies at Portland State University.

Michael Simpson is a PhD candidate in geography at the University of British Columbia and received a MURP from Portland State University in 2014.

Jacinto Pereira Santos is a professor of agronomy at the Universidade Federal do Tocantins, Brazil and was a visiting scholar in the Toulan School of Urban Studies and Planning at Portland State University.

Appendix A.1. Considerations when purchasing vegetables

\begin{tabular}{llccc}
\hline $\begin{array}{l}\text { Question } \\
\begin{array}{l}\text { How important to you are the following considerations } \\
\text { when you purchase vegetables for your household? }\end{array}\end{array}$ & $\begin{array}{l}\text { Response } \\
\text { Not at all } \\
\text { \% of respondents }\end{array}$ & $\begin{array}{l}\text { Only a little } \\
\text { Somewhat } \\
\text { important }\end{array}$ & $\begin{array}{l}\text { Very } \\
\text { important }\end{array}$ \\
\hline Price / affordability & 4 & 16 & 49 & 30 \\
Freshness & 0 & 1 & 12 & 86 \\
Locally grown & 3 & 8 & 55 & 33 \\
Organic or pesticide free & 7 & 14 & 37 & 42 \\
Eating healthy & 0 & 3 & 24 & 73 \\
Vegetarian/vegan diet & 62 & 17 & 11 & 10 \\
Labor practices / farmworker conditions & 18 & 24 & 41 & 17 \\
\hline
\end{tabular}

Appendix A.2. Motivations to produce food

\begin{tabular}{lllll}
\hline $\begin{array}{l}\text { Question } \\
\begin{array}{l}\text { How important are following reasons for why your } \\
\text { household produces food? }\end{array}\end{array}$ & $\begin{array}{l}\text { Response } \\
\text { Not at all } \\
\text { \% of respondents }\end{array}$ & $\begin{array}{l}\text { Only a little } \\
\text { Somewhat } \\
\text { important }\end{array}$ & $\begin{array}{l}\text { Very } \\
\text { important }\end{array}$ \\
\hline To earn money & 97 & 1 & 1 & 0 \\
To save money & 16 & 31 & 32 & 21 \\
To barter / trade without using money & 83 & 11 & 5 & 1 \\
To be self-sufficient & 10 & 19 & 37 & 34 \\
To have enough food to eat & 44 & 26 & 18 & 12 \\
To build community / connect with friends or neighbors & 45 & 29 & 19 & 7 \\
To relax or unwind & 8 & 20 & 40 & 32 \\
To make my yard look nice & 25 & 25 & 37 & 14 \\
To have fresh, nutritious produce & 1 & 3 & 18 & 79 \\
To live in a more environmentally sustainable way & 5 & 11 & 30 & 54 \\
Because I'm concerned about food safety & 17 & 20 & 31 & 32 \\
To educate myself or others & 21 & 21 & 35 & 23 \\
\hline
\end{tabular}




\section{References}

Agyeman, J. (2013). Introducing Just Sustainabilities: Policy, Planning, and Practice. London, UK: Zed Books.

Alaimo, K., Packnett, E., Miles, R. A., \& Kruger, D. J. (2008). Fruit and vegetable intake among urban community gardeners. Journal of Nutrition Education and Behavior, 40(2), 94-101. http://doi.org/10.1016/j.jneb.2006.12.003

Alkon, A. H., \& Agyeman, J. (Eds.). (2011). Cultivating Food Justice: Race, Class, and Sustainability. Cambridge: MIT Press.

Alkon, A. H., Block, D., Moore, K., Gillis, C., DiNuccio, N., \& Chavez, N. (2013). Foodways of the urban poor. Geoforum, 48, 126-135. http://doi.org/10.1016/j.geoforum.2013.04.021

Anselin, L. (1995). Local Indicators of Spatial Association-LISA. Geographical Analysis, 27(2), 93-115. http://doi.org/10.1111/j.1538-4632.1995.tb00338.x

Armstrong, D. (2000). A survey of community gardens in upstate New York: Implications for health promotion and community development. Health and Place, 6, 319-327. http://doi.org/10.1016/S1353-8292(00)00013-7

Barthel, S., \& Isendahl, C. (2013). Urban gardens, agriculture, and water management: Sources of resilience for long-term food security in cities. Ecological Economics, 86, 224-234. http://doi.org/10.1016/j.ecolecon.2012.06.018

Bassett, T. J. (1981). Reaping on the Margins: A Century of Community Gardening in America. Landscape, 25(2), $1-8$.

Bates, L. K. (2013). Gentrification and Displacement Study: Implementing an Equitable Inclusive Development Strategy in the Context of Gentrification. Portland, OR: City of Portland Bureau of Planning and Sustainability. Retrieved from https://www.portlandoregon.gov/bps/article/454027

Boone, C. G., Cadenasso, M. L., Grove, J. M., Schwarz, K., \& Buckley, G. L. (2010). Landscape, vegetation characteristics, and group identity in an urban and suburban watershed: why the 60s matter. Urban Ecosystems, 13(3), 255-271. http://doi.org/10.1007/s11252-009-0118-7

Born, B., \& Purcell, M. (2006). Avoiding the Local Trap: Scale and Food Systems in Planning Research. Journal of Planning Education and Research, 26, 195-297. http://doi.org/10.1177/0739456X06291389

Bowling, A. (2005). Mode of questionnaire administration can have serious effects on data quality. Journal of Public Health, 27(3), 281-291. http://doi.org/10.1093/pubmed/fdi031

Bradley, K., \& Galt, R. E. (2014). Practicing food justice at Dig Deep Farms \& Produce, East Bay Area, California: self-determination as a guiding value and intersections with foodie logics. Local Environment, 19(2), 172186. http://doi.org/10.1080/13549839.2013.790350

Checker, M. (2011). Wiped Out by the "Greenwave": Environmental Gentrification and the Paradoxical Politics of Urban Sustainability. City \& Society, 23(2), 210-229. http://doi.org/10.1111/j.1548-744X.2011.01063.x

City Farmer. (2002). 44\% of Vancouver Households Grow Food says City Farmer. Retrieved from http://cityfarmer.org/44percent.html\#44percent

City of Portland. (2012). Urban Food Zoning Code Update Recommended Draft. Portland: Bureau of Planning and Sustainability. Retrieved from http://www.portlandoregon.gov/bps/article/398119

City of Portland, \& Multnomah County. (2009). Climate Action Plan 2009. Portland: Bureau of Planning and Sustainability. Retrieved from www.portlandonline.com/bps/climate

CoDyre, M., Fraser, E. D. G., \& Landman, K. (2015). How does your garden grow? An empirical evaluation of the costs and potential of urban gardening. Urban Forestry \& Urban Greening, 14(1), 72-79. http://doi.org/10.1016/j.ufug.2014.11.001

Cohen, N., \& Reynolds, K. (2014). Urban Agriculture Policy Making in New York's "New Political Spaces" Strategizing for a Participatory and Representative System. Journal of Planning Education and Research, 34(2), 221-234. http://doi.org/10.1177/0739456X14526453

Comstock, N., Miriam Dickinson, L., Marshall, J. A., Soobader, M.-J., Turbin, M. S., Buchenau, M., \& Litt, J. S. (2010). Neighborhood attachment and its correlates: Exploring neighborhood conditions, collective efficacy, and gardening. Journal of Environmental Psychology, 30(4), 435-442. http://doi.org/10.1016/j.jenvp.2010.05.001

Corburn, J. (2009). Toward the Healthy City: People, Places, and the Politics of Urban Planning. Cambridge: MIT Press.

Cortright, J. (2014). The Young and Restless and the Nation's Cities. City Observatory. Retrieved from http://cityobservatory.org/ynr/

Cotugno, A., \& Seltzer, E. (2011). Towards a Metropolitan Consciousness in the Portland Oregon Metropolitan Area. International Planning Studies, 16(3), 289-304. http://doi.org/10.1080/13563475.2011.591147 
Crouch, P. (2012, October 23). Evolution or gentrification: Do urban farms lead to higher rents? Grist. Retrieved from http://grist.org/food/evolution-or-gentrification-do-urban-farms-lead-to-higher-rents/

Davidson, M., \& Lees, L. (2009). New-build gentrification: its histories, trajectories, and critical geographies.

Population, Space and Place, 16(5), 395-411. http://doi.org/10.1002/psp.584

Dobernig, K., \& Stagl, S. (2015). Growing a lifestyle movement? Exploring identity-work and lifestyle politics in urban food cultivation. International Journal of Consumer Studies, 39(5), 452-458. http://doi.org/10.1111/ijcs.12222

Drake, L., \& Lawson, L. J. (2014). Results of a US and Canada community garden survey: shared challenges in garden management amid diverse geographical and organizational contexts. Agriculture and Human Values, 32(2), 241-254. http://doi.org/10.1007/s10460-014-9558-7

Duncan, J. S., \& Duncan, N. G. (2004). Landscapes of Privilege: The Politics of the Aesthetic in an American Suburb. New York: Routledge.

Ghose, R., \& Pettygrove, M. (2014). Urban Community Gardens as Spaces of Citizenship. Antipode, 46(4), 10921112. http://doi.org/10.1111/anti.12077

Gibson, K. J. (2007). Bleeding Albina: A History of Community Disinvestment, 1940-2000. Transforming Anthropology, 15(1), 3-25. http://doi.org/10.1525/tran.2007.15.1.03

Giner, N. M., Polsky, C., Pontius Jr., R. G., \& Runfola, D. M. (2013). Understanding the social determinants of lawn landscapes: A fine-resolution spatial statistical analysis in suburban Boston, Massachusetts, USA. Landscape and Urban Planning, 111, 25-33. http://doi.org/10.1016/j.landurbplan.2012.12.006

Goodling, E. K., Green, J., \& McClintock, N. (2015). Uneven development of the sustainable city: Shifting capital in Portland, Oregon. Urban Geography, 36(4), 504-527. http://doi.org/10.1080/02723638.2015.1010791

Goodling, E. K., \& Herrington, C. (2015). Reversing Complete Streets Disparities: Portland's Community Watershed Stewardship Program. In S. Zavestoski \& J. Agyeman (Eds.), Incomplete Streets: Processes, Practices, and Possibilities (pp. 176-202). New York: Routledge.

Gottlieb, R., \& Joshi, A. (2010). Food Justice. Cambridge: MIT Press.

Gray, L., Guzman, P., Glowa, K. M., \& Drevno, A. G. (2014). Can home gardens scale up into movements for social change? The role of home gardens in providing food security and community change in San Jose, California. Local Environment, 19(2), 187-203. http://doi.org/10.1080/13549839.2013.792048

Grewal, S. S., \& Grewal, P. S. (2012). Can cities become self-reliant in food? Cities, 29(1), 1-11. http://doi.org/10.1016/j.cities.2011.06.003

Groves, R. M., \& Couper, M. P. (1998). Nonresponse in Household Interview Surveys (1 edition). New York: Wiley-Interscience.

Guitart, D. A., Byrne, J. A., \& Pickering, C. M. (2013). Greener growing: assessing the influence of gardening practices on the ecological viability of community gardens in South East Queensland, Australia. Journal of Environmental Planning and Management, 58(2), 189-212. http://doi.org/10.1080/09640568.2013.850404

Hackworth, J. (2007). The Neoliberal City: Governance, Ideology, and Development in American Urbanism. Ithaca: Cornell University Press.

Hanlon, B. (2009). Once the American Dream: Inner-Ring Suburbs of the Metropolitan United States (Reprint edition). Temple University Press.

Harvey, D. (1989). The Urban Experience. Baltimore: The Johns Hopkins University Press.

Heynen, N., Perkins, H., \& Roy, P. (2006). The Political Ecology of Uneven Urban Green Space: The Impact of Political Economy on Race and Ethnicity in Producing Environmental Inequality in Milwaukee. Urban Affairs Review, 42(1), 3-25. http://doi.org/10.1177/1078087406290729

Hodgson, K., Caton Campbell, M., \& Bailkey, M. (2011). Urban Agriculture: Growing Healthy, Sustainable Places. Washington: American Planning Association.

Hunter, M. C. R., \& Brown, D. G. (2012). Spatial contagion: Gardening along the street in residential neighborhoods. Landscape and Urban Planning, 105(4), 407-416. http://doi.org/10.1016/j.landurbplan.2012.01.013

Isard, W. (1967). Methods of Regional Analysis. Cambridge: MIT Press.

Jansson, A. (2013). Reaching for a sustainable, resilient urban future using the lens of ecosystem services. Ecological Economics, 86, 285-291. http://doi.org/10.1016/j.ecolecon.2012.06.013

Jurjevich, J. R., \& Schrock, G. (2012). Is Portland Really the Place Where Young People Go To Retire? Migration Patterns of Portland's Young and College-Educated, 1980-2010 (No. 9-2012). Portland, OR: Population Research Center. Retrieved from http://pdxscholar.library.pdx.edu/prc_pub/5/

Kinzig, A., Warren, P., Martin, C., Hope, D., \& Katti, M. (2005). The Effects of Human Socioeconomic Status and Cultural Characteristics on Urban Patterns of Biodiversity. Ecology and Society, 10(1), 23-36. 
Kirkpatrick, J. B., Daniels, G. D., \& Zagorski, T. (2007). Explaining variation in front gardens between suburbs of Hobart, Tasmania, Australia. Landscape and Urban Planning, 79(3-4), 314-322. http://doi.org/10.1016/j.landurbplan.2006.03.006

Kortright, R., \& Wakefield, S. (2011). Edible backyards: a qualitative study of household food growing and its contributions to food security. Agriculture and Human Values, 28(1), 39-53. http://doi.org/10.1007/s10460-009-9254-1

Krasny, M. E., \& Tidball, K. G. (2009). Applying a resilience systems framework to urban environmental education. Environmental Education Research, 15(4), 465-482. http://doi.org/10.1080/13504620903003290

Kremer, P., \& DeLiberty, T. L. (2011). Local food practices and growing potential: Mapping the case of Philadelphia. Applied Geography, 31(4), 1252-1261. http://doi.org/10.1016/j.apgeog.2011.01.007

Krumholz, N. (1990). Making Equity Planning Work: Leadership in the Public Sector. Philadelphia: Temple University Press.

Lawson, L. J. (2005). City Bountiful: A Century of Community Gardening. Berkeley: University of California Press.

Lee, S., \& Leigh, N. G. (2007). Intrametropolitan Spatial Differentiation and Decline of Inner-Ring Suburbs A Comparison of Four U.S. Metropolitan Areas. Journal of Planning Education and Research, 27(2), 146164. http://doi.org/10.1177/0739456X07306393

Leigh, R. (1970). The Use of Location Quotients in Urban Economic Base Studies. Land Economics, 46(2), 202 205. http://doi.org/10.2307/3145181

Lin, B. B., Philpott, S. M., \& Jha, S. (2015). The future of urban agriculture and biodiversity-ecosystem services: Challenges and next steps. Basic and Applied Ecology, 16(3), 189-201. http://doi.org/10.1016/j.baae.2015.01.005

Li, W. (2011). Ethnoburb. Honolulu: University of Hawaii Press.

Lubitow, A., \& Miller, T. R. (2013). Contesting Sustainability: Bikes, Race, and Politics in Portlandia. Environmental Justice, 6(4), 121-126. http://doi.org/10.1089/env.2013.0018

Lyson, H. C. (2014). Social Structural Location and Vocabularies of Participation: Fostering a Collective Identity in Urban Agriculture Activism. Rural Sociology, 79(3), 310-335. http://doi.org/10.1111/ruso.12041

MacRae, R., Gallant, E., Patel, S., Michalak, M., Bunch, M., \& Schaffner, S. (2010). Could Toronto provide 10\% of its fresh vegetable requirements from within its own boundaries? Matching consumption requirements with growing spaces. Journal of Agriculture, Food Systems, and Community Development, 1(2), 105-127.

Markham, L. (2014, May 21). Gentrification and the Urban Garden. The New Yorker. Retrieved from http://www.newyorker.com/business/currency/gentrification-and-the-urban-garden

Martin, C. A., Warren, P. S., \& Kinzig, A. P. (2004). Neighborhood socioeconomic status is a useful predictor of perennial landscape vegetation in residential neighborhoods and embedded small parks of Phoenix, AZ. Landscape and Urban Planning, 69(4), 355-368. http://doi.org/10.1016/j.landurbplan.2003.10.034

Massey, D. S., \& Denton, N. A. (1993). American Apartheid: Segregation and the Making of the Underclass. Cambridge: Harvard University Press.

McClintock, N. (2010). Why farm the city? Theorizing urban agriculture through a lens of metabolic rift. Cambridge Journal of Regions, Economy and Society, 3(2), 191-207.

McClintock, N. (2014). Radical, reformist, and garden-variety neoliberal: coming to terms with urban agriculture's contradictions. Local Environment, 19(2), 147-171. http://doi.org/10.1080/13549839.2012.752797

McClintock, N., Cooper, J., \& Khandeshi, S. (2013). Assessing the potential contribution of vacant land to urban vegetable production and consumption in Oakland, California. Landscape and Urban Planning, 111, 46-58. http://doi.org/10.1016/j.landurbplan.2012.12.009

McClintock, N., Young, J., Taren, E., Simpson, M., \& Santos, J. (2013). The Landscape of Food Production. Metroscape, (Summer), 13-19.

McPhearson, T., Hamstead, Z. A., \& Kremer, P. (2014). Urban Ecosystem Services for Resilience Planning and Management in New York City. AMBIO, 43(4), 502-515. http://doi.org/10.1007/s13280-014-0509-8

Miller, L. E., \& Smith, K. L. (1983). Handling nonresponse issues. Journal of Extension, 21(5), 45-50.

Moglia, M. (2014). Urban agriculture and related water supply: Explorations and discussion. Habitat International, 42, 273-280. http://doi.org/10.1016/j.habitatint.2014.01.008

National Gardening Association. (2014). Garden to Table: A 5-Year Look at Food Gardening in America. Williston, VT. Retrieved from http://goo.gl/lf4xSD

Naylor, L. (2012). Hired Gardens and the question of transgression: lawns, food gardens and the business of "alternative" food practice. Cultural Geographies, 19(4), 483-504.

http://doi.org/10.1177/1474474012451543 
Okvat, H. A., \& Zautra, A. J. (2011). Community Gardening: A Parsimonious Path to Individual, Community, and Environmental Resilience. American Journal of Community Psychology, 47(3-4), 374-387. http://doi.org/10.1007/s10464-010-9404-z

Ozawa, C. P. (Ed.). (2004). The Portland Edge: Challenges And Successes In Growing Communities. Washington, DC: Island Press.

Pastor, M., Benner, C., \& Matsuoka, M. (2009). This Could Be the Start of Something Big: How Social Movements for Regional Equity are Reshaping Metropolitan America. Ithaca: Cornell University Press.

Pearsall, H. (2012). Moving out or moving in? Resilience to environmental gentrification in New York City. Local Environment, 17(9), 1013-1026. http://doi.org/10.1080/13549839.2012.714762

Pearsall, H., \& Pierce, J. (2010). Urban sustainability and environmental justice: evaluating the linkages in public planning/policy discourse. Local Environment, 15(6), 569-580. http://doi.org/10.1080/13549839.2010.487528

Pearson, L. J., Pearson, L., \& Pearson, C. J. (2010). Sustainable urban agriculture: stocktake and opportunities. International Journal of Agricultural Sustainability, 8(1-2), 7-19. http://doi.org/10.3763/ijas.2009.0468

Peck, J. (2005). Struggling with the Creative Class. International Journal of Urban and Regional Research, 29(4), 740-770. http://doi.org/10.1111/j.1468-2427.2005.00620.x

Pham, T.-T.-H., Apparicio, P., Séguin, A.-M., Landry, S., \& Gagnon, M. (2012). Spatial distribution of vegetation in Montreal: An uneven distribution or environmental inequity? Landscape and Urban Planning, 107(3), 214-224. http://doi.org/10.1016/j.landurbplan.2012.06.002

Pothukuchi, K. (2009). Community and Regional Food Planning: Building Institutional Support in the United States. International Planning Studies, 14(4), 349-367.

Pourias, J., Aubry, C., \& Duchemin, E. (2015). Is food a motivation for urban gardeners? Multifunctionality and the relative importance of the food function in urban collective gardens of Paris and Montreal. Agriculture and Human Values, 1-17. http://doi.org/10.1007/s10460-015-9606-y

PREP Oregon. (2015). Long-term Resilience. Retrieved June 24, 2015, from http://www.preporegon.org/Resilience

Ramírez, M. M. (2015). The Elusive Inclusive: Black Food Geographies and Racialized Food Spaces. Antipode, 47(3), 748-769. http://doi.org/10.1111/anti.12131

Reynolds, K. (2015). Disparity Despite Diversity: Social Injustice in New York City's Urban Agriculture System. Antipode, 47(1), 240-259. http://doi.org/10.1111/anti.12098

Robbins, P. (2007). Lawn People: How Grasses, Weeds, and Chemicals Make Us Who We Are. Philadelphia: Temple University Press.

Rogus, S., \& Dimitri, C. (2015). Agriculture in urban and peri-urban areas in the United States: Highlights from the Census of Agriculture. Renewable Agriculture and Food Systems, 30(Special Issue 01), 64-78. http://doi.org/10.1017/S1742170514000040

Saldivar-Tanaka, L., \& Krasny, M. E. (2004). Culturing community development, neighborhood open space, and civic agriculture: The case of Latino community gardens in New York City. Agriculture and Human Values, 21(4), 399-412. http://doi.org/10.1007/s10460-003-1248-9

Sbicca, J. (2012). Growing food justice by planting an anti-oppression foundation: opportunities and obstacles for a budding social movement. Agriculture and Human Values, 29(4), 455-466. http://doi.org/10.1007/s10460012-9363-0

Schupp, J., \& Sharp, J. (2012). Exploring the social bases of home gardening. Agriculture and Human Values, 29(1), 93-105. http://doi.org/10.1007/s10460-011-9321-2

Scott, A. J. (2006). Creative Cities: Conceptual Issues and Policy Questions. Journal of Urban Affairs, 28(1), 1-17. http://doi.org/10.1111/j.0735-2166.2006.00256.x

Sen, A. (1983). Poverty and Famines: An Essay on Entitlement and Deprivation. Oxford: Oxford University Press.

Slocum, R. (2007). Whiteness, space and alternative food practices. Geoforum, 38, 520-533. http://doi.org/10.1016/j.geoforum.2006.10.006

Smith, N. (2002). New Globalism, New Urbanism: Gentrification as Global Urban Strategy. Antipode, 34(3), 427450. http://doi.org/10.1111/1467-8330.00249, 10.1111/1467-8330.00249

Smith, V. M., Greene, R. B., \& Silbernagel, J. (2013). The social and spatial dynamics of community food production: a landscape approach to policy and program development. Landscape Ecology, 28(7), 14151426. http://doi.org/10.1007/s10980-013-9891-z

Sugrue, T. J. (2005). The Origins of the Urban Crisis: Race and Inequality in Postwar Detroit. Princeton: Princeton University Press.

Tavernise, S. (2011, September 8). Vegetable Gardens Are Booming in a Fallow Economy. The New York Times. Retrieved from http://www.nytimes.com/2011/09/09/us/09gardening.html 
Taylor, J. R., \& Lovell, S. T. (2012). Mapping public and private spaces of urban agriculture in Chicago through the analysis of high-resolution aerial images in Google Earth. Landscape and Urban Planning, 108(1), 57-70. http://doi.org/10.1016/j.landurbplan.2012.08.001

Taylor, J. R., \& Lovell, S. T. (2014). Urban home food gardens in the Global North: research traditions and future directions. Agriculture and Human Values, 31(2), 285-305. http://doi.org/10.1007/s10460-013-9475-1

Taylor, J. R., \& Lovell, S. T. (2015). Urban home gardens in the Global North: A mixed methods study of ethnic and migrant home gardens in Chicago, IL. Renewable Agriculture and Food Systems, 30(1), 22-32. http://doi.org/10.1017/S1742170514000180

Thibert, J. (2012). Making Local Planning Work for Urban Agriculture in the North American Context: A View from the Ground. Journal of Planning Education and Research, 32(3), 349-357. http://doi.org/10.1177/0739456X11431692

van den Berg, L. M., Kemeling, I., \& Roerink, G. J. (2001). Urban agriculture in Ouagadougou and Bamako: Estimating its spatial distribution with the help of IKONOS high resolution satellite imagery. National Remote Sensing Program (NRSP-2), Netherlands.

Ville de Montréal. (2013). Agriculture urbaine, Sondage auprès de la population de l'île de Montréal -. Retrieyed April 2, 2015, from http://donnees.ville.montreal.qc.ca/dataset/agriculture-urbaine-sondage

Voicu, I., \& Been, V. (2008). The effect of community gardens on neighboring property values. Real Estate Economics, 2, 241-283.

Walk Score. (2014). Get Your Walk Score. Retrieved February 6, 2015, from www.walkscore.com/score

Wekerle, G. R. (2004). Food Justice Movements: Policy, Planning, and Networks. Journal of Planning Education and Research, 23, 378-386.

White, M. M. (2011). D-Town Farm: African American Resistance to Food Insecurity and the Transformation of Detroit. Environmental Practice, 13(04), 406-417. http://doi.org/10.1017/S1466046611000408

Wolch, J. R., Byrne, J., \& Newell, J. P. (2014). Urban green space, public health, and environmental justice: The challenge of making cities "just green enough." Landscape and Urban Planning, 125, 234-244. http://doi.org/10.1016/j.landurbplan.2014.01.017 